UCLA-ENG--860B

DE 86012969

\title{
MASTER
}

UCLA-ENG-8608

PPG-934

\section{Modeling of Tritium Transport in \\ a Pin-Type Solid Breeder Blanket}

\author{
Rodger Martia and Nasr M. Ghonien
}

February 1986

\section{DISCLAIMER}

\begin{abstract}
This seport was prepered as an accoust of wosk sponsored by sn agency of the United Stules Government. Neither the United States Government nos any atency thereor, nor any of their employees, makes any warranty, express or inplied, or assumes any legal liability or reaponajbility for the accuracy, comptetences, of usefulness of any information, apperatus, product, or process discloved, or represents that its use would not infringe privalely owned rights. Reference herein to any apecific cormmercisl product, process, or service by trade name, trademark, masufacturer, or otherwive does not necesuarily constitute or inply its endorecment, recommendation, or favoring by tbe Uniled States Goverament or any agency thereof. The view and opinions of authors expreseed berein do not necessarily state or reflect those of the United Sintes Government of any arency thereof.
\end{abstract}

Support by a University of Callfornia Los Angeles Chancellor's Fellowship is eratefully acknowledged. The support of U.S. Department of Enerzy, Grant \#DE-C03-00ER52061, to UCLA is appreciated. 


\section{DISCLATHA}

This report was prepared as an account of work sponsored by an agency of the United States Governeent. Neither the United States Government nor any agency thereof, nor any of their emplojees, wakes any warranty, express or Implled, or aseunes any legal liabillty or responalbility for the accuracy, completeness, or usefulness of any 1nforaction, apparatus, product, or process disclosed, or represents that Its use would not infringe privately orned rights. Reference herein to any specific comerclal product, process, or service by trade name, tradenark, manufacturer, or otherwise, does not necessarfly constitute or Inply its endorsewent, recomendation, or favoring by the United States Government or any agency thereof. The view and opinions of authors expressed hereln do not necessarily state or reflect those of the United States Government or any agency thereof. 
CONTENTS

LIST OF FIGURES . . . . . . . . . . . . . . . . . . . iv

1. Introduction ........................ 1

2. Previous Efforts in Tritium Transport Modeling ............ 3

3. Modeling of Tritium Transport for the Current Blanket Design . . . . . 14

4. Comparison of DIFFUSE ResuIts to Other Models . . . . . . . . . . . 17

5. Steady-state Tritium Inventory . . . . . . . . . . . . . 18

6. Transient Tritium Inventory . . . . . . . . . . . . . . . . 28

7. Additional DIFFUSE Modeling . . . . . . . . . . . . . 36

8. Sumary and Recommendations ... . . . . . . . . . . . . . 39

ACKNOWLEDGEMENTS . . . . . . . . . . . . . . . . . . . 40

REFERENCES .............................. . . 41 
1. Temperature Dependence of Diffusion Coefficients of IIitium, Oxygen, LIthium, Hydrogen, and Deuterium in $\mathrm{LI}_{2} \mathrm{O}$. . . . . . . . . 2

2. Partial Pressure of $\mathrm{H}_{2} \mathrm{O}$ above the Diphasic $\mathrm{Li}_{2} \mathrm{O}$ (solid) - LiOH (solid, liquid) System as a Function of Temperature . . . . . . . 4

3. Schematic of Tritium Inventory Phenomena . . . . . . . . . . . . . . 6

4. Volumetric Heating, First Zone . . . . . . . . . . . . . . . . . . . 8

5. Volumetric Heating for Zone 2. . . . . . . . . . . . . . . . . . . . 9

6. Tritium Generation Rate, First Zone . . . . . . . . . . . . . . . . . 10

7. Tritium Generation Rate, Second Zone . . . . . . . . . . . . . . . 11

8. Diffusive Inventory in $\mathrm{LiAlO}_{2}$ vs. Temperature . . . . . . . . . . . . 19

9. $\mathrm{LiAlO}_{2}$ Tritium Inventory vs. Grain Size . . . . . . . . . . . . . . 20

10. LiAlO 2 Time to steady-state vs. Temperature . . . . . . . . . . . . . 21

11. TC Time to Steady-state vs. Grain Size . . . . . . . . . . . . . . . 22

12. Effect of Dfffusion Coefficient on Inventory . . . . . . . . . . . . 23

13. Total Blanket Inventory, Row by Row . . . . . . . . . . . . . . . 26

14. Comparison of Tritium Inventory Models . . . . . . . . . . . . . . . 27

15. Total Tritium Inventory during Startup Transients . . . . . . . . . . 30

16. Inventory at End of Each Transient, Rows 1 to $5 . . . . . . . . . . . .31$

17. Inventory at End of Each Transient, Rows 6 to 11 . . . . . . . . . 32

18. Total Tritium Inventory after Shutdown, No Heating . . . . . . . . . 34

19. Total Tritium Inventory after Shutdown . . . . . . . . . . . . . . . 35

20. Tritium Inventories, Different Surface Phenomena . . . . . . . . . 38 


\section{INTRODUCTION}

This study supplements a larger study of a solid breeder blanket design featuring lithium ceramic pins. This aspect of the study looks at eritium transport, release, and inventory within this blanket design. $\mathrm{Li}_{2} \mathrm{O}$ anct $\gamma-\mathrm{LiAlO}_{2}$ are the two primary candidates for ceramic solid breeders. $\gamma-\mathrm{LiAlO}_{2}$ was chosen for this blanket design due to its higher structural stability. Analysis of tritium behavior in solid breeder blankets is of great importance due to its impact on several critical issues: the generation of an adequate amount of fusion fuel, the safecy-related issue of keeplng radioactive blanket inventories as low as possible, and the release, purge, and economical processing of the bred tritiun without undue contamination of the coolant and other reactor structures.

Tritium inventory is related to both transport (diffusive) and solubility (thermodynamic) properties (1). Tritium recovery is achieved by passing helium through the purge channels and porosity of the ceramic to sweep out the tritium. Tritium diffusion plays a najor role in determining tritium inventory: the slower the diffusion, the longer the residence time within the blanket, and the greater the diffusive inventory. This phenomenon is very temperature sensitive, with the diffusion coefficient generally varying as:

$$
D-D_{0} \exp (-Q / R T)
$$

where $Q$ is the activation energy for diffusion in kcal/mol, $R$ is the ideal gas constant equal to $1.987 \times 10^{-3} \mathrm{kcal} / \mathrm{mol} /{ }^{\circ} \mathrm{K}, \mathrm{D}_{\mathrm{o}}$ is a pre-exponential factor, and $T$ is in units of degrees Kelvin. Both $D$ and $D_{0}$ are in units of $\mathrm{cm}^{2} / \mathrm{sec}$. Experimentai determination of diffusion coefficients is very important in estimating blanket inventories. Experiments on both $\mathrm{Li}_{2} \mathrm{O}$ and $\mathrm{LiAlO} \mathrm{O}_{2}$ show wide variations in the experimental coefficlents, likely due to both variations in experimental conditions and in the grain sizes used in each experiment. Figure 1 shows this situation for $\mathrm{Li}_{2} \mathrm{O}$.

For $\mathrm{Li}_{2} \mathrm{O}$, the recent BCSS and FINESSE studies $(2,3)$ have used the diffusion coeficicient obtained by Guggi et al. (4) because of the well characterized grain sizes used and the controlled experimental conditions:

$$
\ln \left(\mathrm{D} / \mathrm{cm}^{2} \mathrm{~s}^{-1}\right)-(5.93 \pm 0.48)-(19.52 \pm 1.01 \mathrm{kcal} / \mathrm{mol} / \mathrm{RT})
$$

measured between 850 and $1200^{\circ} \mathrm{K}$.

$\mathrm{LiAlO}_{2}$ shows even greater variation in experimental coefficients. Brining, Guggl, and Ihle ( 5 ) deternined a value of:

$$
\text { ln }\left(D / \mathrm{cm}^{2} \mathrm{~s}^{-1}\right)=-5.78-(19.3 \mathrm{kcal} / \mathrm{mol} / \mathrm{RT})
$$

between 878 and $1178^{\circ} \mathrm{K}$. However, the TRIO-01 experiment ( 6 ) determined a value of:

$$
\ln \left(\mathrm{D} / \mathrm{cm}^{2} \mathrm{~s}^{-1}\right)=(-13.7 \pm 1.8)-(35.8 \pm 3.9 \mathrm{kcal} / \mathrm{mo} 1 / \mathrm{RT})
$$




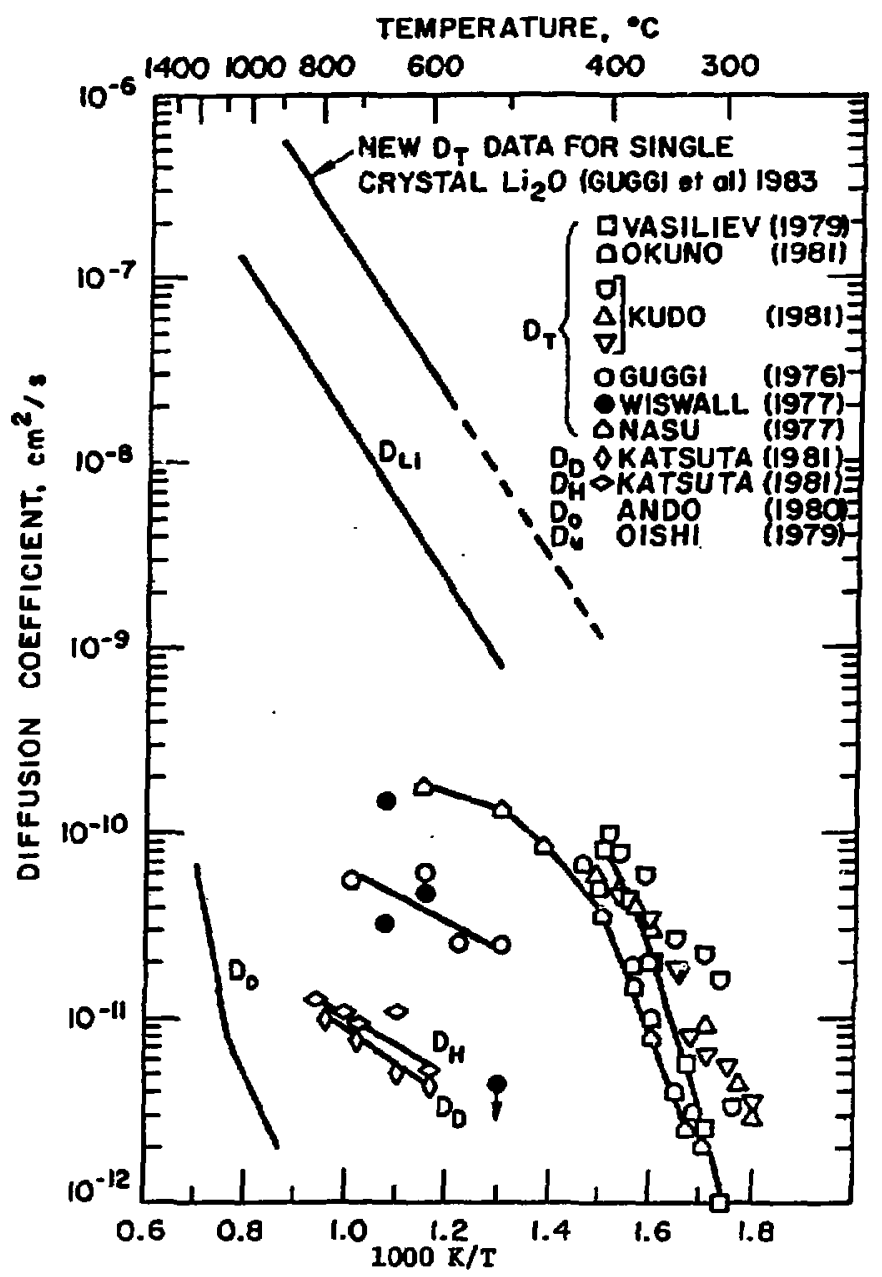

FIgure 1: Temperature dependence of diffusion coefficients of tritium, oxygen, lithlum, hydrogen, and deuterium in $\mathrm{Li}_{2} \mathrm{O}$. 
which has been taken as the reference value in the BCSS and FINESSE reports. Choice of $D$ can change the calculated tritium inventory by several orders of magnitude; this mandates an accurate characterization of the coefficient for the relevant blanket conditions.

The solubility effect is most significant for $\mathrm{Li}_{2} \mathrm{O}$, with increased tritium Inventory from HTO/ $\mathrm{T}_{2} \mathrm{O}$ dissolution and LIOT formation:

$$
\mathrm{Li}_{2} \mathrm{O}(\mathrm{s}\rangle+\mathrm{H}_{2} \mathrm{O}(\mathrm{g}) \rightarrow 2 \mathrm{LiOH}\langle\mathrm{s}) .
$$

One experinent was reported (1) which measured the solubility of $\mathrm{H}_{2} \mathrm{O}$ in $\mathrm{LH}_{2} \mathrm{O}$ as a function of temperature from 973 to $1273^{\circ} \mathrm{K}$ to give an analytical expression for the concentration of dissolved LiOH:

$$
\begin{aligned}
\log \left(X_{L i O H}\right)=(0.427 & \left.+1.700 \times 10^{-4} \mathrm{~T}\right) \log \left(\mathrm{P}_{\mathrm{H} 2 \mathrm{O}}\right) \\
& +\left(-17.667+2.502 \times 10^{-2} \mathrm{~T}-9.62 \times 10^{-6} \mathrm{~T}^{2}\right)
\end{aligned}
$$

where $X_{\mathrm{LiOH}}$ is the mole fraction of L1OH, $P_{\mathrm{H} 20}$ is the gas phase partial pressure of $\mathrm{H}_{2} \mathrm{O}$ in atmospheres, and the temperature is in degrees Kelvin. The chenical properties of hydrogen and tritiun are virtually identical.

Above a threshold pressure of $\mathrm{H}_{2} \mathrm{O}$ a separate LiOH/T phase will form, tying up tritiun in a sable form difficult to remove fron the bulk of the $\mathrm{Li}_{2} \mathrm{O}$ ceramic. Experimental values for this critical pressure were deternined in the range of 573 to $894^{\circ} \mathrm{K}$ (7):

$$
\begin{array}{lll}
\log P_{\mathrm{H} 20}=-6718 / \mathrm{T}+6.45, & T<723^{\circ} \mathrm{K} \\
\log \mathrm{P}_{\mathrm{H} 2 \mathrm{O}}=-4406 / \mathrm{T}+3.27, & \mathrm{~T}>723^{\circ} \mathrm{K}
\end{array}
$$

with $723^{\circ} \mathrm{K}$ the melting point of LiOH. These results are given in Figure 2, Higher temperature allows a hfgher critical partial pressure of $\mathrm{H}_{2} \mathrm{O}$ before onset of $\mathrm{LIOH} / \mathrm{T}$ phase formation, but It also increases the LiOH/T solubility (equation 6 ).

Experimental values of activity coefficient data indicate thernodynanic non-ideality for $\mathrm{Li}_{2} \mathrm{O}$ (9). A positive deviation fron ldeality was deternined indicating a lower $\mathrm{LIOH}$ solubility than for an ideal solution, a favorable result for decreased tritium inventory. The thernodynamic data used for ideal solution calculations was taken fion the JANAF tables (10).

The greater LiOH solubility at higher temperatures and partial pressures of $\mathrm{H}_{2} \mathrm{O}$ has another unfavorable result: greater LiOH vapor pressure outside the $\mathrm{Li}_{2} \mathrm{O}$ cerbinic causing lithiun transport from the ceramic and the structural corrosion probleas associated with LiOH.

\section{PREVIOUS EFFORTS IN TRITIUM TRANSPORT MODELING}

One of the earliest attempts to model tritiun blanket inventory was the STARFIRE (II) reactor study. The model was relatively crude, using macroscopic variables in a percolation model to approxinate $T_{2} 0$ partial pressures within the large pores, and using an assuned average partial 


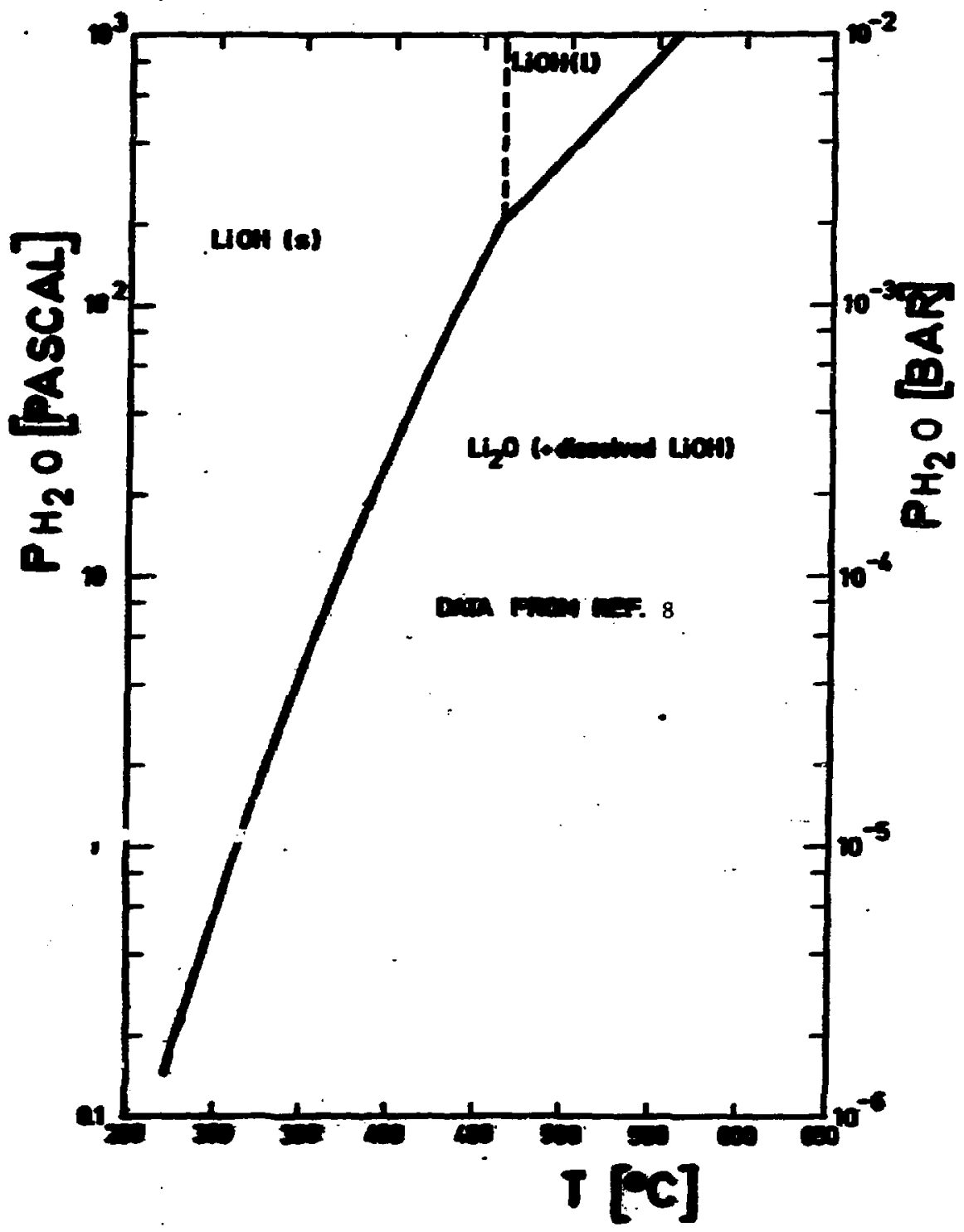

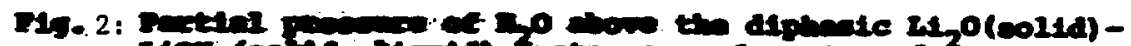

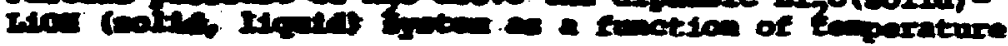


pressure of one torr in the $\mathrm{LiAlO}_{2} / \mathrm{Al}_{2} \mathrm{O}_{3}$ equilibrium to obtain a very approximate value of $13 \mathrm{wppn}$ tritiun or $8.1 \mathrm{~kg}$ of blanket inventory at $1000^{\circ} \mathrm{K}$ and 18 lithium burn-up.

Far more refined models were devised for the BCSS and FINESSE studies to approximate blanket inventories. All nodels begin with the simple analytical solution of tritium diffusion in a spherical ceranic grain. By assuning zero tritium concentration at the grain boundary, a simple equation can be established for the inventory within the grain:

$$
I_{g}-\tau \dot{g} v_{g}
$$

with the mean residence time within the grain given by:

$$
\tau=\mathbf{r}_{g}{ }^{2} / 15 D \text {. }
$$

$D$ is the previously defined diffusion coefficient, $r_{g}$ the grain radius, $\dot{g}$ the tritium generation rate in grams/sec/cm, and $v_{g}$ the grain volume. After applying various sumnations and correction factors for the temperature and/or generation profiles over unit cells and the blenket as a wole (described below), a value is obtained for the tritiun diffusive inventory ( $I_{d}$ ) throughout the blanket. Additional inventory can be associated with tritium solubility within the ceranic $\left(I_{s}\right)$, adsorption of tritiun on the surfaces of the grains and the larger pellets $\left(I_{a}\right)$, tritiun diffusing through the grain boundaries $\left(I_{g}\right)$, and tritiun passing out through the purge gas within the porosity/percolation/purge strean convection $\left(I_{p}\right)$. The entire inventory within the breeder can then be represented by:

$$
I_{b}-I_{d}+I_{s}+I_{a}+I_{g}+I_{p} \text {. }
$$

These interrelated fhysical phenomena can be visualized using the schenatic in Figure 3. If the entire inventory throughout the blanket is considered, then contributions due to contanination of the coolant $\left(I_{c}\right)$ and the metal structure from permeation $\left(I_{m}\right)$ can be added:

$$
I_{\text {total }}=I_{b}+I_{c}+I_{\mathbf{n}} \text {. }
$$

Models have been devised to approximate all inventory contributions within the breeder except for grain boundary diffusion. Each model has assumed that, analogous to diffusion within metals, the transport of tritiun within the grain boundaries is so rapid relative to the bulk diffusion rates that it could be neglected as a significant contribution to total blanket inventory.

Frow the basic equation for diffusive inventories within a sphere, an equation can be established to represent the diffusive inventory within a characteristic unit cell of the blanket:

$$
I_{\text {cell }}=\int_{V_{\text {cell }}} \tau \dot{g}(I-\epsilon) d V \text {. }
$$

with $\epsilon$ the fraction of porosity within the breeder. The diffusive inventory is calculated by suming over all unit cells.

For plate-type solid breeders, with the length of the plate and the 
Figure 3: Schematic of Tritium Inventory Phenomena

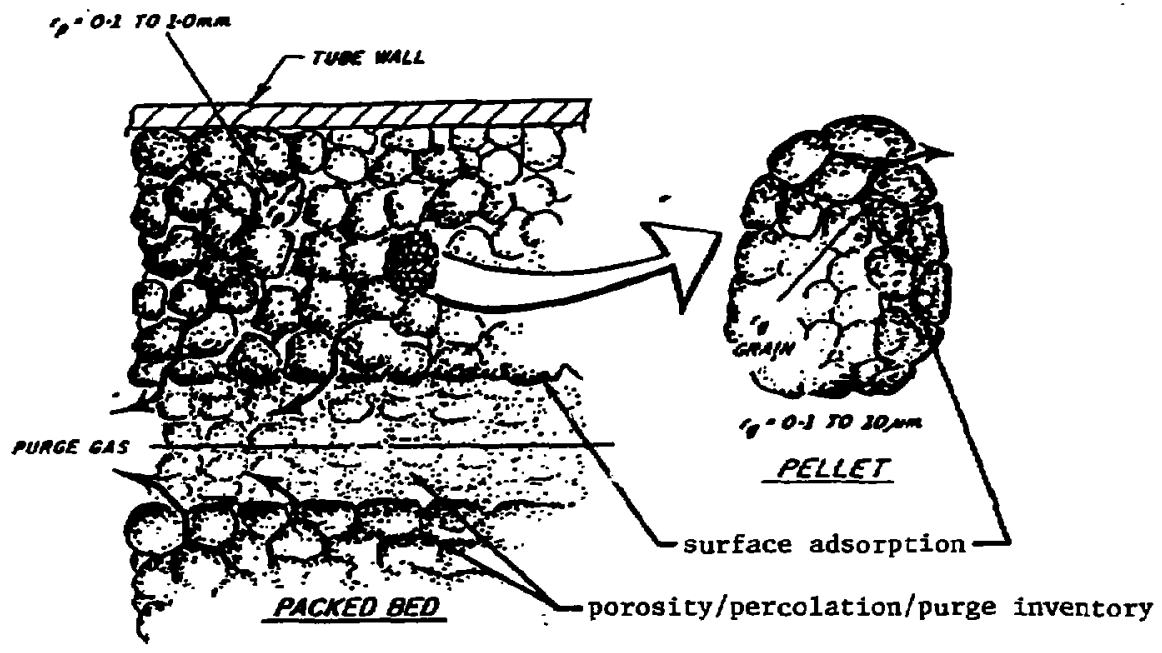

granular structure
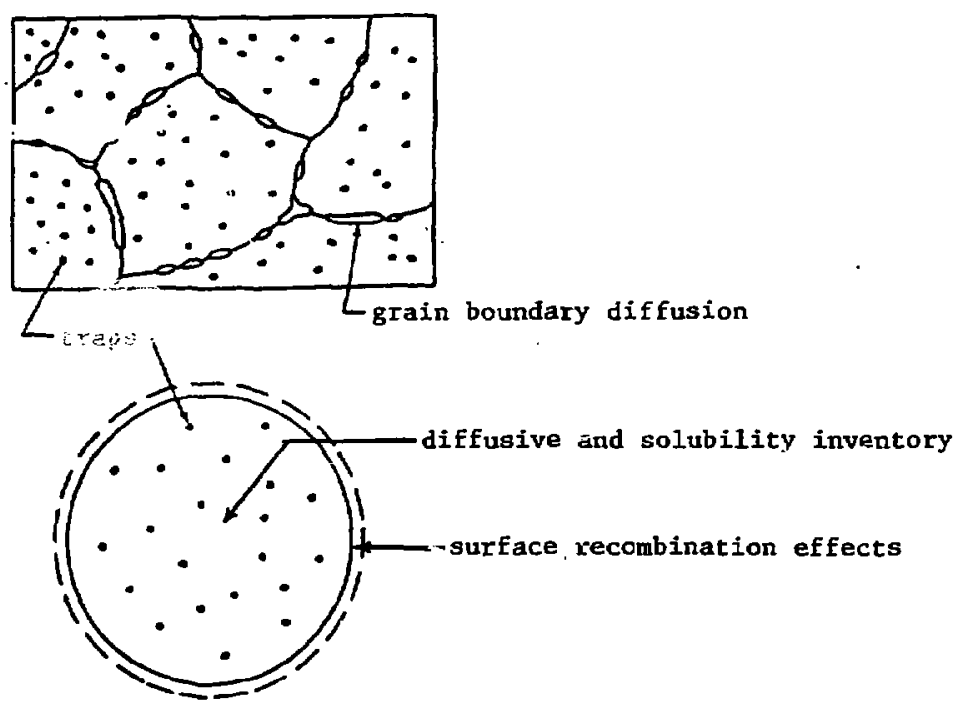

spherical grain 
coolant path positioned radially from the plasma, the above equation is converted to:

$$
\left(I_{d}\right)_{p l a t e}=\dot{G}_{p} \int_{-1 / 2}^{1 / 2} h(\xi)\left[\int_{0}^{1} \tau(\eta, \xi) d \eta\right] d \xi
$$

with $\dot{\mathrm{G}}_{\mathrm{p}}$ the total generation rate for the plate in grams/sec, $\xi$ the nornalized position along the coolant path, $h(\xi)-\dot{g}(\xi) / \bar{g}$ the normalized tritiun production rate along the $\xi$ direction, $\eta$ the normalized position along the thickness of the plate, and $\tau$ defined by equat ions 1 and 9 but with $T-T(\xi, \pi)$. The only published results fron this $m$ tel. (12) used the simplifylng assumption of both blanket heating rate and tritium generation rate varying with the same exponential dependence along the coolant path, 1.e.:

$$
\dot{g}(\xi)=\dot{g}_{\max } \exp [-\alpha(\xi+1 / 2)] .
$$

Different values of $\alpha$ were then ued for purposes of comparison. For detalled calculations, this study found equation 14 to be not applicable over the entire blanket. The results of a prelininary neutronics calculation vere plotted in Figures 4 through 7 to test this approxination. Although the exponential dependence with radial position is true on average, the greater neutron populations just beyond the berylliun zone and reflected by the shield cause significant deviation from the exponential approximation.

Models of cylindrical unit cells exploy tio simpler equation:

$$
\left(I_{d}\right)_{c y l}=f \dot{G}_{c y l} r_{g}{ }^{2} / 15 D(\bar{T})
$$

where

$$
f=(\beta-1)^{-1} \int_{1}^{\beta} \exp [(Q / R \bar{T})(\bar{T} / T-1)] d \eta
$$

with $\beta=r_{0}{ }^{2} / r_{i}{ }^{2}$ and $\eta-r^{2} / r_{i}{ }^{2}$ for $r_{i}$ the unit cell inner radius, $r_{0}$ the unit cell outer radius, and $r$ and $T$ the local position and temperature at any point between $r_{1}$ and $r_{0}$. This equation requires evaluation of the diffusion coeffictent at only one value, the volune-averaged temperature $\bar{T}$, for each init cell. Equations can be used for $T$ and $T, g i v e n T_{\max }$ and $T_{m i n}$, or actual values can be used for a known or given temperature proifile.

For the solubility inventory, BCSS (13) first makss a calculation for an assumed situation for $\mathrm{LI}_{2} \mathrm{O}$ to make a qualitative comparison with $\mathrm{I}_{\mathrm{d}}$; the result was a solubllity inventory of about ten times the diffusiva. A more realistic evaluation was then employed by BCSS (14) using temperature profiles over a blanket-averaged breeder pellet and calculated pressure and concentration distributions of $T_{2} 0$ within the breeder pores to obtein a solubility Inventory about 3300 times that of the diffusive inventory for a $\mathrm{Ii}_{2} \mathrm{O}$ blanket.

Estimates of low to negligible tritium solubility inventories for Lisloc were thermodynamically evaluated or assumed by several studies: STARFIRE, the GA Technologies Inc. model in BCSS (14), and the TRIO experiment.

Inventory based on surface adsorption is a big question due to linited 
F1gure 4

VOLUMETAIC HEATING, FIRST ZONE

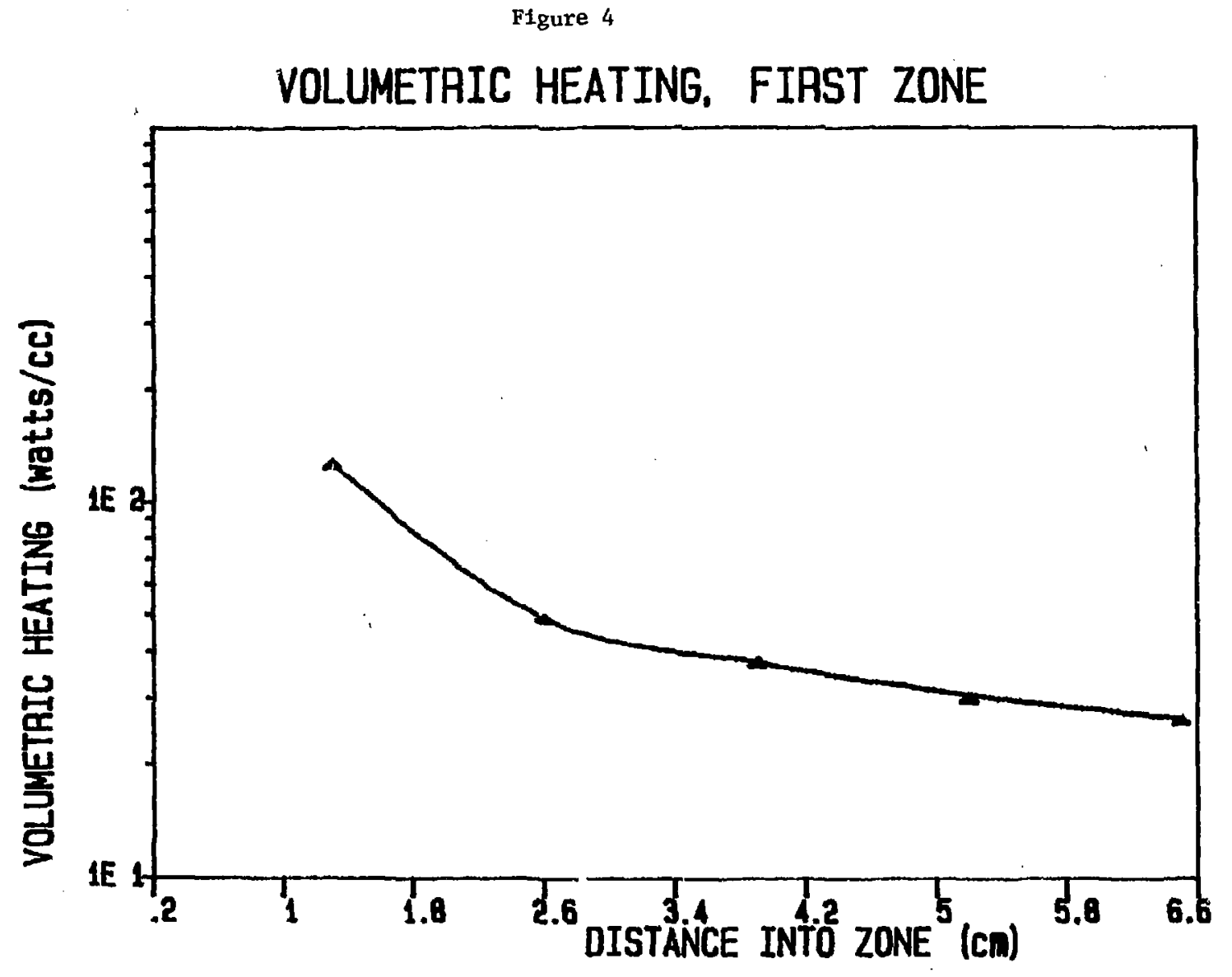


Figure 5

VOLUMETHIC HEATING FOR ZONE 2

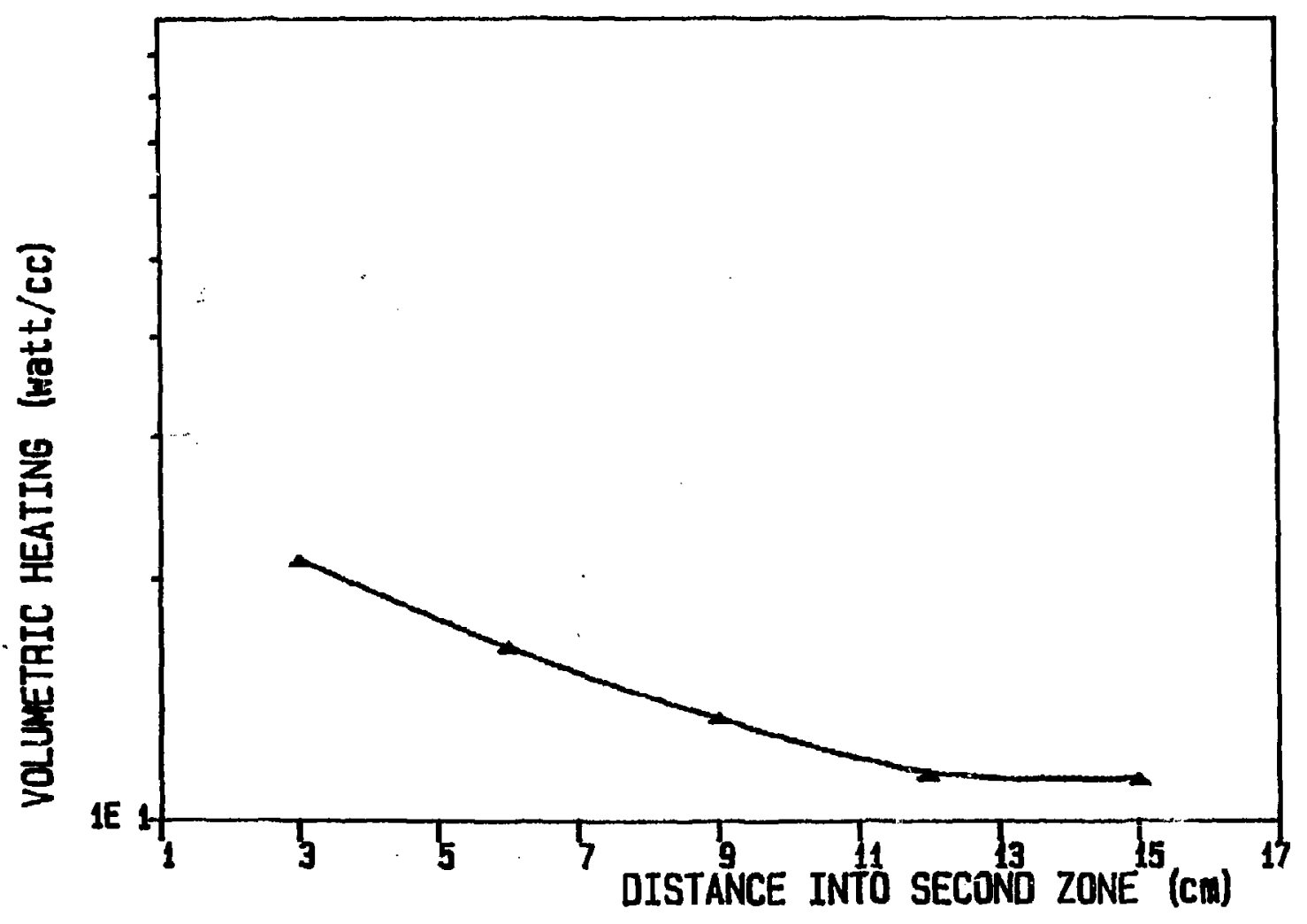


Figure 6

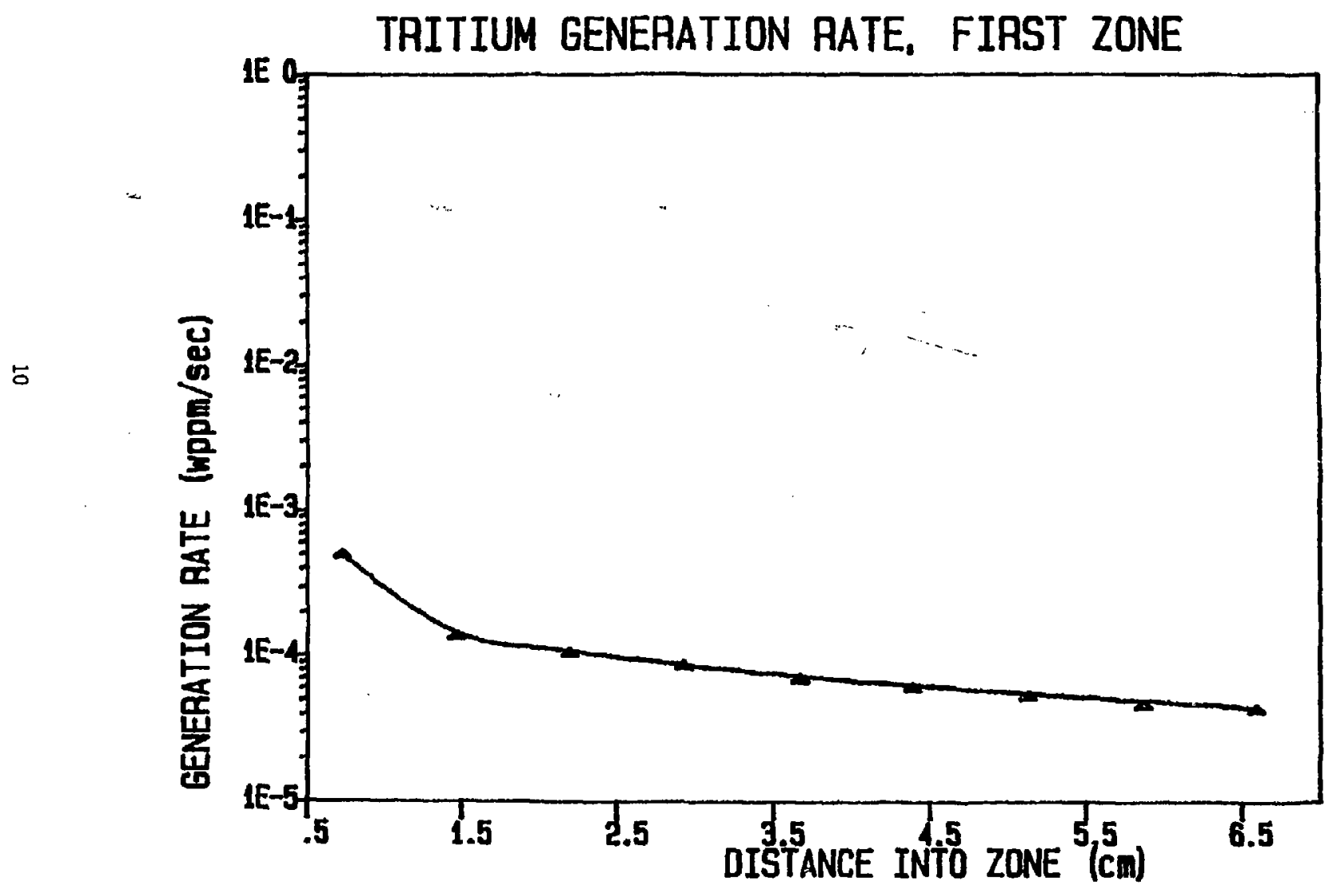


Figure 7

TAITIUM GENERATION RATE, SECOND ZONE

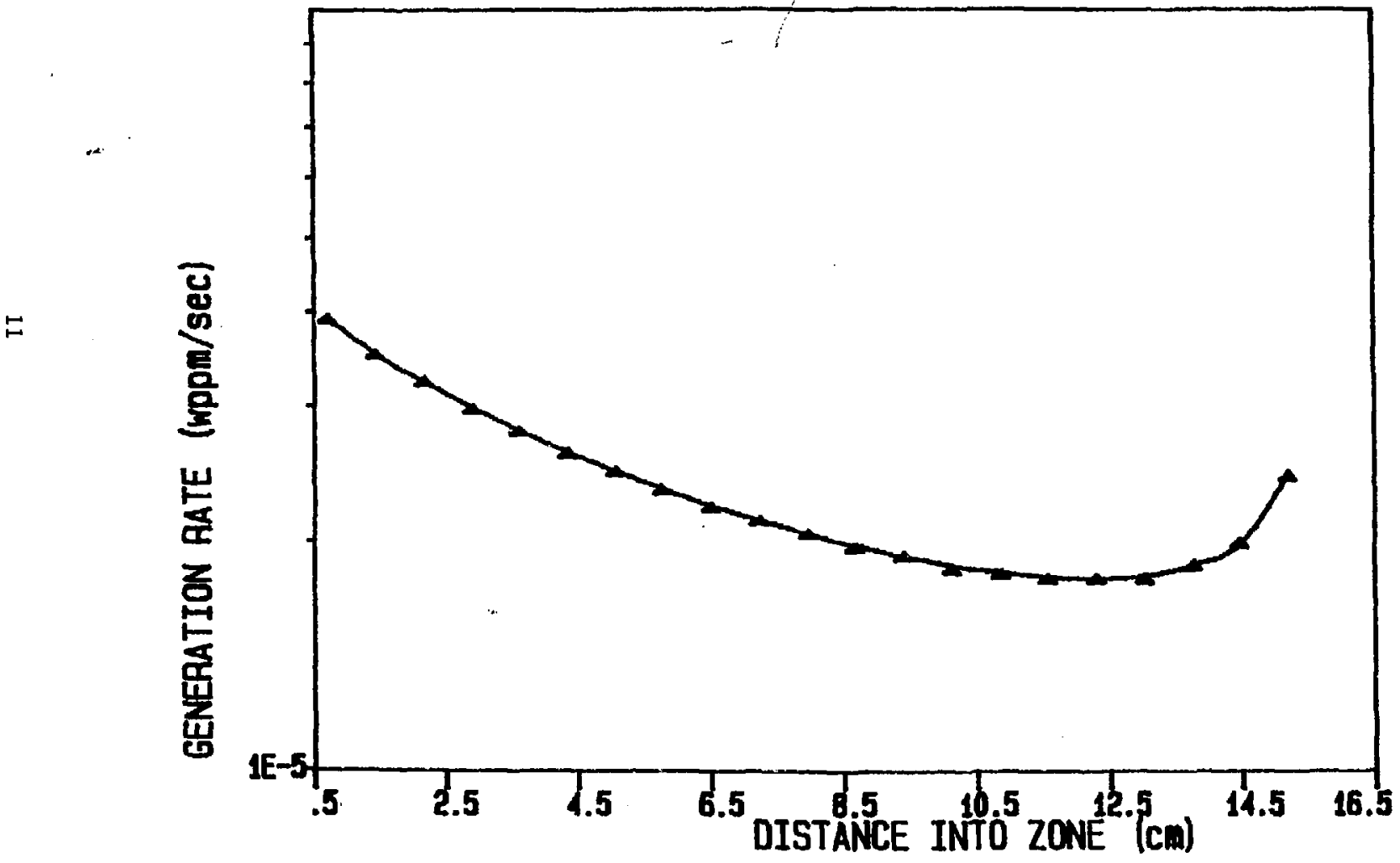


experimental data and problems of interpretation of results. The only experinent attempting to interpret surface effects is the TRIO experiment. Thirty-three irradiation runs of $\gamma-\mathrm{LiAlO}_{2}$ pellets were made under varying conditions. Those runs with $0.1 \%$ hydrogen in the helium purge gas were interpreted to exhibit bulk diffusion as the rate-liniting step; tritium release was assuneci to be uninhibited by surface adsorption, and the surface inventory was assuned to be negligible. Any changes in tritiun release due to alteration of purge stream composition was attributed to surface effects and a non-negligible surface inventory. The conclusions drawn were $I_{a}-3 \pm 2$ wppm for $\mathrm{ILAlO}_{2}$ blankets with pure hellum purge and $\mathrm{I}_{\mathrm{a}}-0$ for 0 . I $\mathrm{H}_{2}$ within the purge gas. Both BCSS and FINESSE assured $0.18 \mathrm{H}_{2}$ in the purge gas and used the $I_{a}-0$ assumption in modeling $\mathrm{LiAlO}_{2}$ blankets.

The inventory attributed to porosity/percolation/purge stream transport can be approximated by applying nass balance and Ideal gas law considerations to an equation fron BCSS (15):

$$
P_{A}=\left(P_{A}\right)_{1}+\frac{(1 / \epsilon-1) R \bar{I} \dot{B}_{A} r_{1}^{2} E(\beta)}{4 W_{A} D_{e}(\bar{T})}
$$

where $A$ is the tritiun specles, $\left(P_{A}\right)_{i}$ the partial pressure of $A$ in the purge strean, $\epsilon$ the interconnected (as opposed to closed) porosity fraction, $\overline{\mathbf{T}}$ the average tenperature within the porosity, $\dot{g}_{A}$ the generation rate of $A$ per urit of 100 dense ceramic volune, $w_{A}$ the molecular weight of $A, f(\beta)=\ln \beta-\beta+1$ for maximun $P_{A}$ or $f(\beta)-\left(1^{A}-\beta^{-1}\right)^{-1}$ in $\beta-1$ for average $P_{A}$, and all else defined as before. These equations assume a cylindrical unit cell with the purge tube located next to the central coclant tube. The ratio of the mean free path for molecular collisions to the average pora radius $\lambda / r_{p}$ determines what equation to use for the calculation of $D_{e}(\bar{T})$. Different values of $D_{e}(\bar{T})$ are obtained if the transport of the tritiun specles within the porosity is dominated by Knudsen diffusion, ordinary nolecular diffusion, or some interuediate regine. FINESSE (16) reports an error of \pm 20 with this model and its assumption of an isothermal unit cell, and calculates a typical rise in tritiun partial pressure across a unt cell of less than one pascal.

The GA Technologies model of tritiun inventories for the BCSS holiun-cooled blanket design is the only one to approximate porous inventories in a blanket design. For all BCSS blanket designs, a value of $0.04 \mathrm{~g}$ tritium within the porosity was calculated. This GA model, based on the TRIT4 computer code, is the most comprehensive to date in attempting to simultaneously model the diffusive, solubility, and porous contributions to tritiun inventory. However, it still suffers from the weaknesses of the assumptions it employs, and the limited experimental basis upon which those assumptions were made. The assumptions of both the $G A$ and other models which require greater scrutiny are discussed belor.

No model has yet been compared to a nunerical analysis of inventory over the blanket based on calculated temperature and tritium generation profiles. The only model using radial temperature and generation profiles assumed idealized exponential spatial dependencies identical for both profiles, and then analyzed the results for three different examples of exponential decrease. All other models simply applied average volunetric heating and generation rates to a blanket;averaged unit cell, and scaled up to an 
approximate tritiun inventory. The overall accuracy of this approach has not been evaluated.

All models are based on experimental diffusion coefficients which vary significantly fron one experinent to another. This uncertainty is especiaily true for $\mathrm{LiAlO}_{2}$. For example, the Briting et al. values (5) would substantially reduce the calculeted diffusive inventory and renove perhaps the greatest argunent against the use of $\mathrm{LLAlO}_{2}$ with respect to $\mathrm{Li}_{2} \mathrm{O}$.

Only one transport node has been considered significant in any of the models, that of bulk diffusion and release. All models assune the surface inventory and grain boundary effects to be negliglble, and only limited attempts have been made to investigate their roles. A real question remains over the relevance of surface effects. As mentioned previously, surface effects and inventories were assumed significant for $\mathrm{LLAlO}_{2}$ in a pure helium purge stream in the TRIo experinent.

The simplest possible boundary condition has been used in all models, i.e. zero concentration of all tritiun species on the spherical grain surfaces. Any non-zero boundary value assumptions would alter the aralytical solutions for the diffusive inventories.

Solubility effects are poorly modeled at present. The GA model made solubility calculations for $\mathrm{L}_{2} \mathrm{O}$, but $\mathrm{It}$ appears an average $\mathrm{T}_{2} \mathrm{O}$ partlal pressure within the porosity was calculated using equation 17 , and the thermodynanlc equilibriun equations for L $1 O H$ solubility were employed for an overall solubility 1mventory. Lack of background for the TRIT4 calculations precludes detailed analysis. A model more detailed than average equilibriun caleulations may be in order.

Effects due to chenical reactions, particularly oxidation and reduction effects within the breeder and purge strean, are very poorly understood. The large majority of experinents prior to TRIO found $\mathrm{T}_{2} \mathrm{O}$ to be the predoninant tritiun species released fron the breeder. However, TRIO determined 94 of the release to be in the form of HT and $T_{2}$. The asss of the released species may affect the calculations for $I_{p}$ (although this is insignificant compared to $I_{d}+I_{s}$ values), but more inportant are the problens of tritiun permeation through the metal structures and coolant which are far more severe for HT and $T_{2}$ than for HTO or $T_{2} O$. Any oxidation effects within the breeder itself could have profound effects on tritium inventory and release, as TRIo discovered when $0.28 \mathrm{O}_{2}$ was added to the purge stream and release kinetics were disturbed well after the purge was returned to the $\mathrm{H}_{2} /$ He combination. Experinental evidence (17) of globular elemental lithium, a potent reducing agent, has been found after irradiation. Some thermodynamic calculations indicate preferential release of HT or HTO under different oxygen activity regines (18). None of these effects has been incorporated into comprehensive model of tritiun inventory.

A major weakness of all inventory calculations is the total lack of any radiation effects models. No firn conclusion of radiation effects can be drawn from the experiments $(6,19)$, most of which were based on snall 11thium burn-ups relative to blanket lifetines. Signiflcant radiation trapping and detrapping would have profound effects on tritiun release calculations. 
No significant modeling of the change of ceramic properties over time has been done, e.g. grain growth, pore closure dus to sintering, possible formation of release pathways by internal gas generation, restruciuring of the solid and pores over time (as with uranium oxide fuels), effects this restructuring will have on thermal conductivity, temperature, and diffusive profiles, and the effects extended lithium burn-up will have on tritium generation and inventory profiles across the blanket. The discussion of the GA model mentions the use of reduced thermal conductivities for $\mathrm{Li}_{2} \mathrm{O}$ and $\mathrm{LiAlO}_{2}$ under high neutron fluence, but no discussion is made of any time-dependent effects.

Additional modeling is also needed for change of inventory and release profiles under start-up, shutdown, and non-continuous operation. Little work has been done in this area: lialted modeling of a few TRIO transients and some calculations of tritiun release and inventory fractions over time for one of the BCSS LIAlO 2 blankets.

\section{MODELING OF TRITIUM TRANSPORT FOR THE CURRENT BLANKET DESIGN}

Blanket tritiun release and inventory for this pin-type solid breeder design is based on the DIFFUSE code developed by M. Baskes $(20,21)$. This code provides nunexical solutions of the diffusion equation for one or two diffusing; species in up to five different materials. Although primarily designed to study hydrogen perneation effects in metals, it can also model tritiun generation, inventory, and release in solid breeders by a convenient choice of input parameters.

DIFFUSE calculates the one dimensional diffusion of atoms within a material of specified properties for a variety of initial, source, and boundary conditions. The diffusive equations used are given by Fick's laws:

$$
J_{j}(x, t)--D_{j}(T(x, t))\left[\nabla c_{j}(x, t)+\frac{c_{j}(x, t) Q^{*}}{k T(x, t)^{2}} \nabla T(x, t)\right]
$$

and

$$
\partial c_{j}(x, t) / \partial t=-\nabla J_{j}(x, t)+G_{j}(x)-\sum_{i} \partial c_{T}{ }^{1 j}(x, t) / \partial t
$$

where $c_{j}(x, t)$ is the concentration of the $j^{\text {th }}$ diffusing species, $c_{T^{1 j}}(x, t)$ represents the concentration of the $f^{\text {th }}$ species in the $i^{\text {th }}$ trap, $Q^{*}$ is the heat of transport, $G_{j}(x)$ is the implant (generation) source term for the $j$ th species, and all other terms have the standard meanings.

Solutions can be obtalned for planar, spherical, and cylindrical goometries, where the spheres and cylinders can be hollow or solid. Trapping of the diffusing species can be nodeled by DIFFUSE, a very convenient feature for modeling radiation trapping effects. For the $1^{\text {th }}$ type of trap, the governing equations are:

$$
\begin{aligned}
& \partial c_{T}{ }^{i j}(x, t) / \partial t=D_{j}(T(x, t)) c_{j}(x, t) G^{I_{T}}(x, t) / \lambda^{2} \\
& \text { - } c_{T}^{1]}(x, t) \nu_{0} \exp \left[-\left(E_{t}^{1}+E_{d}\right) / k T(x, t)\right]
\end{aligned}
$$


and

$$
c^{1}{ }_{T}(x, t)-c^{1} T_{0}(x)-\sum_{j} f^{1} c_{T}^{1 J}(x, t)
$$

where $c^{i} \mathrm{Te}(x, t)$ is the effective concentration of the $1^{\text {th }}$ trap, $c^{i} T_{0}(x)$ is the actual concentration of the ${ }^{\text {th }}$ trap, $\lambda$ is the junp distance, $\nu_{0}$ is the detrapping attenpt frequency, $E_{F}{ }^{i}$ is the ${ }^{\text {th }}$ trap energy, $E_{d}$ is the activation energy for diffusion, and $f^{f}$ is the inverse trap saturability for the $1^{\text {th }}$ trap.

Tritiun decay to helium can also be modeled as a trap:

$$
\partial c_{\mathrm{T}}{ }^{i l}(x, t) / \partial t-\gamma c_{1}(x, t)
$$

with $\gamma$ the tritium decay constant and the resultant helium considered to be the first trap for diffusing tritiun.

The source of the diffusing species can be modeled as an inplantation, a diatomic gas perneation of surfaces, or an initial concentration. Two traps and/or two implantation profiles are sllowed simultaneously. By using both the Inplantation and initial concentration provisions, hosogeneous steady-state tritiun generation can be modeled within the material. The initial conditions for diffusing and trapped species are given by:

$$
c_{j}(x, 0)-c_{j, 0}(x)
$$

and

$$
c_{T}^{1 j}(x ; 0)-c_{T o}{ }^{i j}(x) \text {. }
$$

Five types of boundary confitions are avaliable in DIFFUSE:

(1) a perfectly reflecting boundary:

$$
J_{f}\left(x_{s}, t\right)-0,
$$

(2) zero concentration at the boundary:

$$
c_{j}\left(x_{s}, t\right)=0,
$$

(3) Sievert's law which models bulk solubility due to gas pressure at the surface:

$$
c_{j}\left(x_{s}, t\right)=S\left[T\left(x_{s}, t\right), P(t)\right] x_{j}(t),
$$

with $S(T, P)$ the solubility, $P(t)$ the total pressure, and $X_{f}(t)$ the mole fraction of the $j^{\text {th }}$ species in the gas phase;

(4) recombination of single atons into a diatonic nolecule at the surface prior to release:

where

$$
\begin{aligned}
J_{j}\left(x_{s}, t\right)=\sum_{j} k_{j j^{\prime}} & {\left[T\left(x_{s}, t\right)\right]\left[c_{j}\left(x_{s}, t\right) c_{j}\left(x_{s}, t\right)\right.} \\
- & \left.x_{j}(t) x_{j}(t) S\left[T\left(x_{s}, t\right), P(t)\right]^{2}\right]
\end{aligned}
$$

$$
K_{j j} \cdot(T)=\frac{4 \alpha c_{1} \exp \left[\left(2 E_{s}-E_{x}\right) / k T\right]}{P \sqrt{\left(M_{j}+M_{j}\right) T} S_{0}^{2}}
$$


and

$$
E_{X}=\operatorname{MAX}\left(E_{s}+E_{d}, 0\right)
$$

with $K_{j},(T)$ is the recomination constant for the $j^{\text {th }}$ and $j^{\text {th }}$ species, $\alpha$ is a sticking coefficient, $c_{I}$ is a kinetic theory constant, $E_{g}$ is the heat of solution, $E_{X}$ is the surface barrier erergy, $\rho$ is the matrix density, and $M_{j}$ is the nass of species $j$;

(5) a simple interface between two materials which mandates continuity of flux and chenical potential of the diffusing species:

$$
J_{j}\left(x_{i}-t\right)-J_{j}\left(x_{1}+, t\right)
$$

and

$$
\frac{c_{j}\left(x_{1}^{-}, t\right)}{S^{-}\left(T\left(x_{1}, t\right), P\right)}=\frac{c_{j}\left(x_{i}{ }^{+}, t\right)}{S^{+}\left(T\left(x_{1}, t\right), P\right)}
$$

Both diffusivity and solubility of the material are assuned to exhibit Arthenius behavior, i.e.

$$
D_{j}(T)-D_{0} H_{j}-1 / 2 \exp \left(-E_{d} / K I\right)
$$

and

$$
S(T, P)-S_{0} P^{1 / 2} \exp \left(-E_{s} / k T\right)
$$

with $D_{0}$ and $S_{0}$ the pre-exponential terms.

Additional features of DIFFUSE are provisions for different temperatures at each interface (and thus a linear temperature profile across each material), diffarent partial pressures of the diffusing gas at the outer surfaces, and linear heating ramps at the interfaces and surfaces and linear pressure ramps at the surfaces.

The value of applying DIFFUSE to blanket tritiun phenonena is its ability to analyze a variety of geonetries, boundary conditions, and naterial paraneters under different blanket conditions. This versatility gives both consistency in modeling and a convenient tool to approxinate blanket inventories with a minimum of analytical modeling. DIFFUSE can approximate both experinental results and the inventory values of sone BCSS and FINESSE models. Good agreement between DIFFUSE and the other nodels would encourage use of DIFFUSE for calculations of blanket inventory and release. THe provisions for surface effects (reconbination and solubility), trapping, and a variety of material and boundary conditions in DIFFUSE permit relatively straightforward analysis of these effects, unlike the analytical models presently enployed which require a piecemeal approach to model each Individual phenonenon.

Another significant advantage of DIFFUSE is the use of results from one time/temperature/generation step as the input to a new step using different input paraneters. This feature nakes DIFFUSE Ideal for analyzing transient behavior in a straighforward and self-consistent manner, e.g. for the analysis of reactor start-up and shutdown effects on tritium behavior. The provision for temperature and pressure ramps over time is another major aid in transient modeling. 


\section{COMPARISON OF DIFFUSE RESULTS TO OTHER MODELS}

Only linited numerical results are available in BCSS and FINESSE for given input parameters with which DIFFUSE outputs can be compared. Two analyses are given in FINESSE (22) directly amenable to DIFFUSE analysis. The first is an analysis of a $\mathrm{Li}_{2} \mathrm{O}$ plate design, for input paraneters of 10 micron grain radius, tritiun generation rate of $1.85 \times 10^{-5}$ wppos $/ \mathrm{s}, 510^{\circ} \mathrm{C}$ minimum and $795^{\circ} \mathrm{C}$ maximum temperature, and the diffusion coefficient given by equation (2). FINESSE applied a value $\alpha=0$ to equation (14) and converted equation (13) to the forn:

$$
I_{d}=\left[r_{g}^{2} \dot{G} / 1 D_{0}\right] E \exp (Q / R T)
$$

where

$$
f=\int_{0}^{1} \exp [(Q / R T)(\bar{T} / T-1)] d \xi \text {. }
$$

For $\alpha=0$, both temperature and generation profiles are constant across the blanket, making the above equations amenable to a DIFirUSE analysis of a characteristic $\mathrm{Li}_{2} \mathrm{O}$ grain for the given paraneters.

The above equations were converted to the form:

$$
I_{d}-\frac{r_{g}^{2} \dot{G}}{15 D_{0} \exp (-Q / R T)} \exp (-Q / R \bar{T}) \int_{0}^{1} \exp (Q / R T) d \xi
$$

for

$$
T=T_{\min }+\left(T_{\max }-T_{\min }\right)\left(1-\xi^{2}\right) \text {. }
$$

Note that the first texn on the right hand side of equation (37) is identical to the spherical grain model of equations (8) and (9). This tern should correspond to the DIFFUSE output, and the folldwing two terms can be evaluated numerically. The average temperature was calculated to be $700^{\circ} \mathrm{C}$. FINESSE reported a result of $2.09 \times 10^{-5}$ wppn inventory. The DIFFUSE-based evaluation gave an inventory of $2.05 \times 10^{-5}$ wppn, differing 1.98 from the FINESSE value.

FINESSE also evaluated a $\mathrm{LiAlO}_{2}$ plate using the s.ine equations, a diffusion coefficient given by equation $(14)$, and input values of 0.1 micron grain radius, a generation rate of $2.41 \times 10^{-5} \mathrm{wpps} / \mathrm{s}$, and $520^{\circ} \mathrm{C}$ ninimu and $1000^{\circ} \mathrm{C}$ maximun temperatures. The average temperature was calculated to be $840^{\circ} \mathrm{C}$. FINESSE reported a value of 0.0460 wppm inventory. The DIFFUSE-based result gave a value of $0.0440 \mathrm{wppn}$, a difference of 4.3 from FINESSE.

As another comparison, the same input values for $\mathrm{Li}_{2} \mathrm{O}$ and $\mathrm{LLAlO}_{2}$ were applied to the spherical grain model of equations (8) and (9). The DIFFUSE inventory results for a single grain were conpared directly to calculated values obtained using:

$$
I_{d}=r_{g}^{2} \dot{G} /\left[15 D_{0} \exp (-Q / R T)\right] \text {. }
$$

For $\mathrm{L}_{2} \mathrm{O}$, equation (39) gave an Inventory of $1.13 \times 10^{-5}$ wppn while DIFroSE gave an inventory of $1.11 \times 10^{-5}$ wpp, a difference of only $1.8 \%$. For L1A10 equation (39) gave a value of $1.58 \times 10^{-3} \mathrm{wppu}$ and DIFFUSE gave a result of 
$1.51 \times 10^{-3}$, a difference of 4.48 .

For aII comparisons, DIFFUSE results agreed with the models well within 58. These results are very compatible and support the conclusion that the DIFFUSE code can be used to provide valid results for diffusive tritium inventories within spherical grains comparable to those of other conmonly used models.

\section{STEADY-STATE TRITIUM INVENTORY}

Having verifled the DIFFUSE results to be comparable to other models, the code was then used to explore the effects of several of the relevant parameters on diffusive inventory. Having chosen $\mathrm{LiAlO}_{2}$ as the candidate solid breeder, grains of this material were nodeled using the diffusion coefficient obtained from TRIO and the arbitrary tritium generation rate of $2.41 \times 10^{-5}$ wppm $/ \mathrm{s}$.

The effects of temperature and grain size on diffusive inventory were analyzed. The results are shown in Figures 8 and 9 . The temperature range relevant to this blanket design, approximately 800 to $1400{ }^{\circ} \mathrm{K}$, was used in these figures. Figure 8 indicates substantial inventory build-up as the temperature decreases below $800^{\circ} \mathrm{K}$, encouraging design of higher temperature blankets. Figure 9 shows a rapid increase in inventory as the grain sizes become larger; this figure supports the BCSS choice of 0.1 micron grain radii, the same size as chosen for this blanket design.

A parameter relevant to transient effects is the time to steady-state diffusive inventories as a function of temperature and grain size, shown in Figures 10 and 11 . This steady-state condition represents a tritium release rate equal to the generation rate. For a 0.1 micron $L_{i A l O}$ grain, Figure 10 shows tine to steady-state varying fron a few seconds at high temperatures to days at low temperatures. Figure il shows a simflar increase in time to steady-state as the grain size increases.

In agreenent with the results of early nodeling efforts, the only component of ceramic tritium inventory used in this evaluation of steady-state Inventory was the diffusive Inventory within the grains. The other modes of transport, grain boundary diffusion, solubility and surface effects, and porosity/purge stream transport were all assumed negligible compared with the magnitude of the diffusive inventory. By considering only diffusive inventory within the grain, we can model the entire blanket inventory by a judicious choice of characteristic grains to represent different portions of each rod. By scaling up the steady-state inventories of these grains, we can obtain approximations for the entire blanket diffusive inventory.

To analyze the effect of diffusion coefficient on steady-state inventory, the two reported values for $\mathrm{LiAlO}_{2}$ in equations (3) and (4) were used as input to DIFFUSE in modeling the diffusive inventory as a function of temperature for a typical grain. A major variation in results is obvious in Figure 12 across the entire temperature range, up to seven or eight orders of magnitude. Use of the larger diffusion coefficient reported by Brifining et al. would lead to insignificant inventories and renove one of the najor advantages claimed 
Figure 8

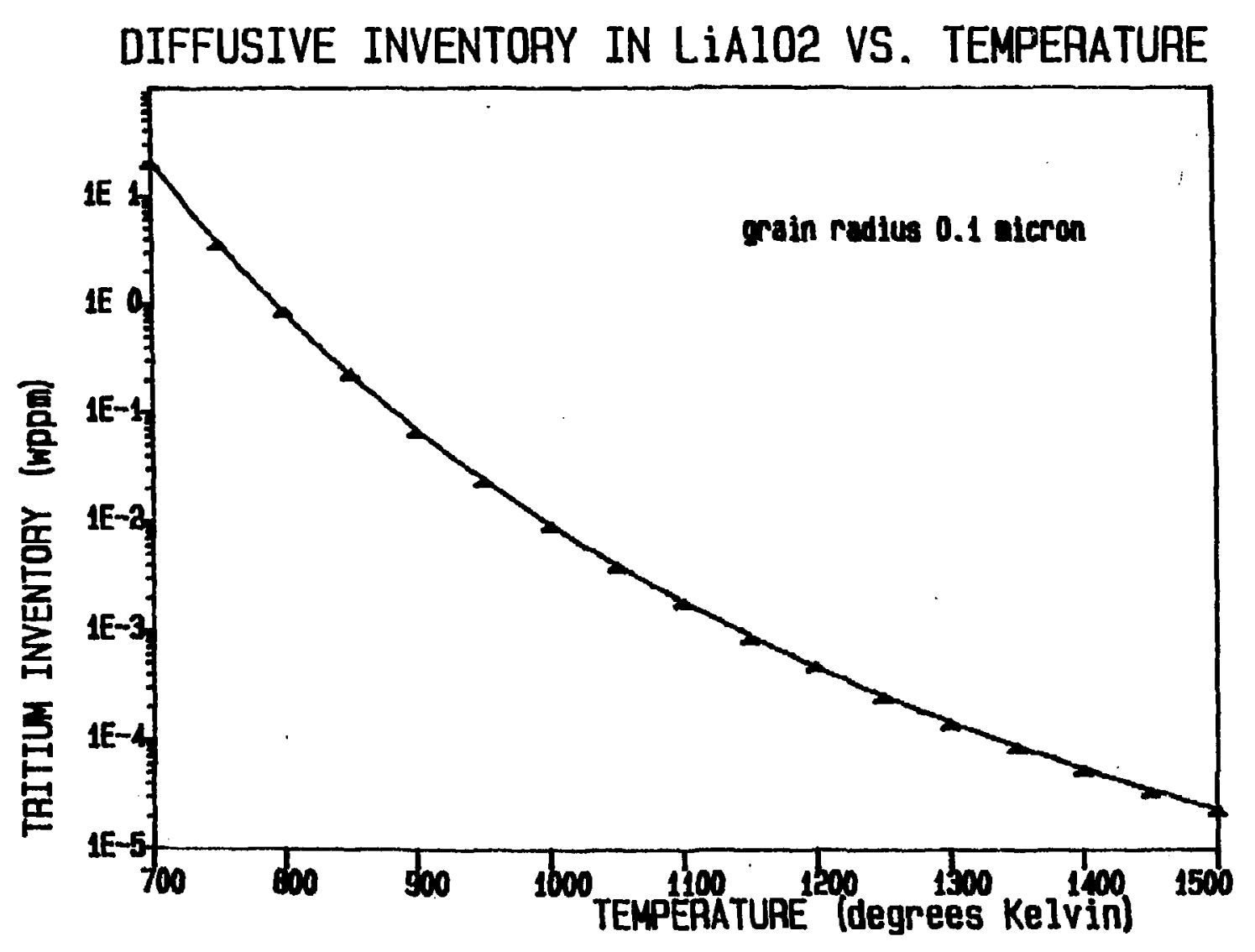


Figure 9

LiA102 TRITIUM INVENTORY VS. GRAIN SIZE (1300 K)

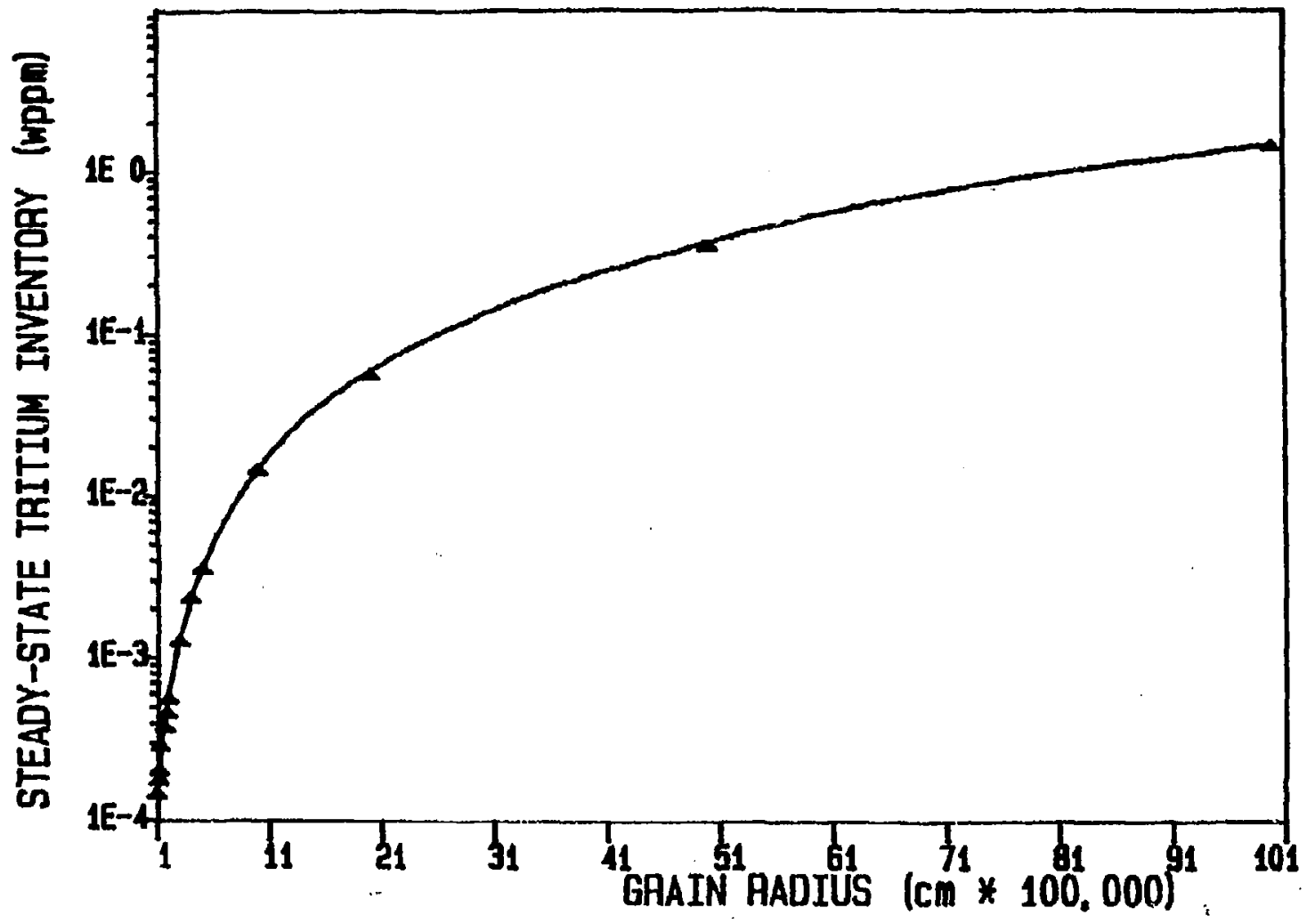


Figure 10

\section{LIAI02 TIME TO STEADY-STATE VS. TEMPERATURE}

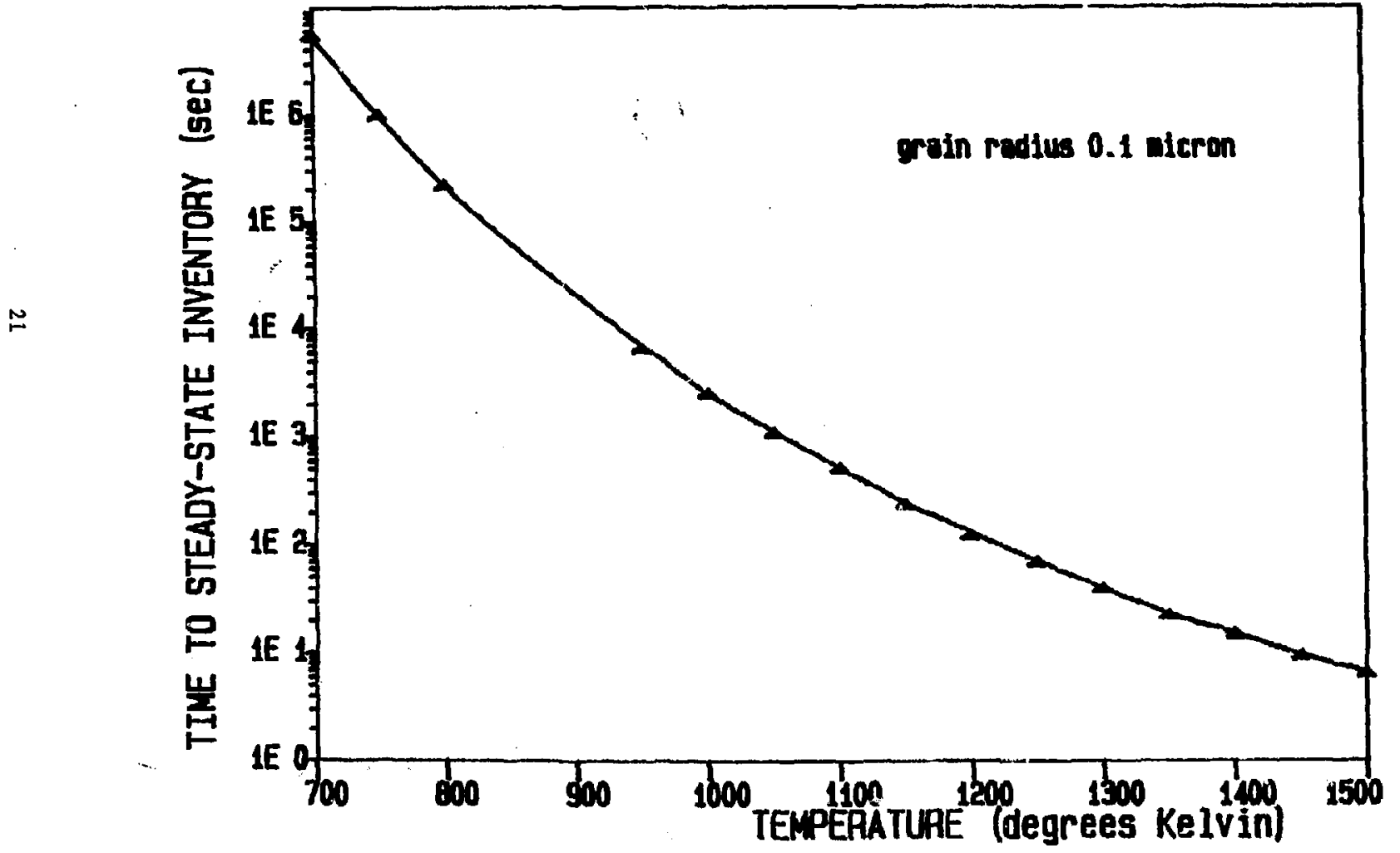


F1gure 11

N

TC TIME TO STEADY-STATE VS. GRAIN SIZE ( $T=1300 \mathrm{~K}$ )

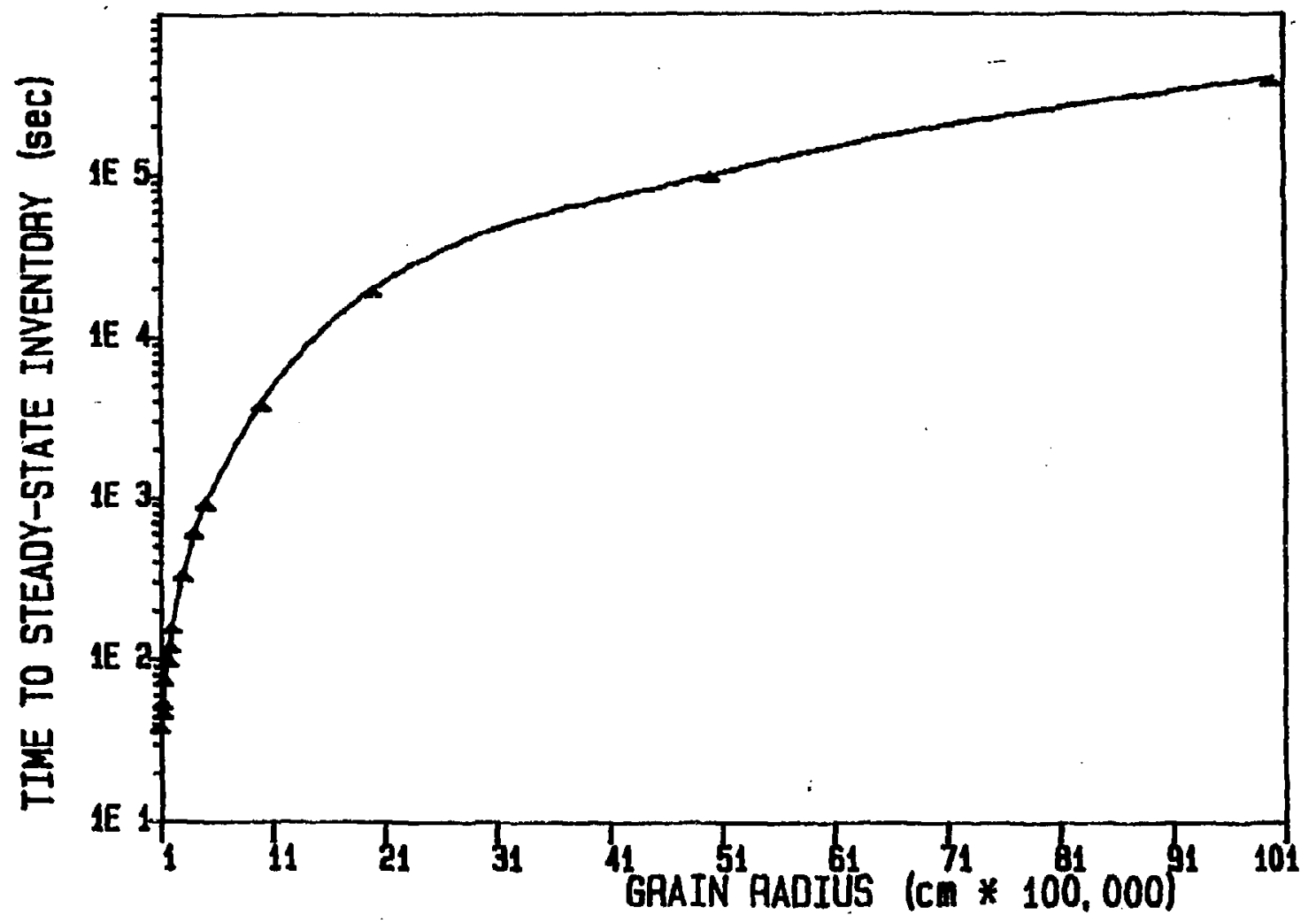


Figure 12

$\tilde{\omega}$

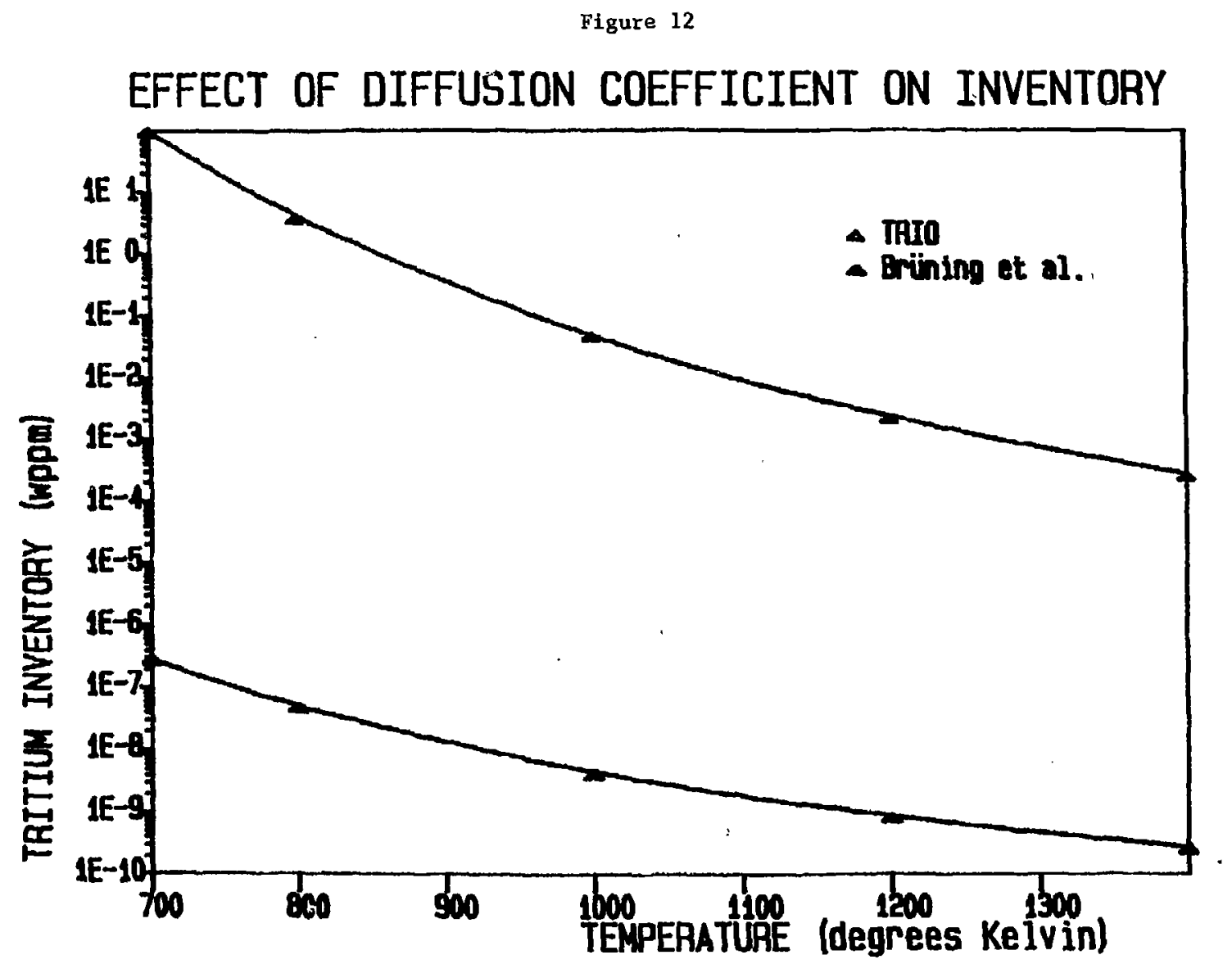


for $\mathrm{Li}_{2} \mathrm{O}$ over $\mathrm{LiAlO}_{2}$ as a tritium breeder. However, the TRIO value was obtained fron an in-situ reactor experiment and may more accurately reflect actual operating conditions. For this reason, the TRIO value was chosen over the Brining et al. value for modeling $\mathrm{LIAlO}_{2}$ in BCSS, FINESSE, and in this study.

The input values for tritium generation rate were obtained from the results of neutronics analysis. The generation rate for each pin was taken to be its axial value in graphs of generation rate (in wppa/s) vs. distance into the module. Asymatries in generation rate across the pin should largely average out from front to back. The largest error might cone in the first row, where the generation profile is very steep. Previous thermal hydraulic analyses provided the average coolant temperature at each row of pins. Application of a standard heat transfer equation to the row by row volumetric heating rates gave the temperature profile within each pin. For steady-state conditions, the maximum central pin tempersture approached $1150^{\circ} \mathrm{C}$ and the minimun outer temperature was slightly above $530^{\circ} \mathrm{C}$. These relatively high temperatures played a major role in keeping total blanket inventory to a minimum.

Some question exists of the behavior of $\mathrm{LiAlO}_{2}$ at the maximum temperatures, since this exceeds the $900^{\circ} \mathrm{C}$ experimental temperatures used in the detailed FUBR-1A experiments with $\mathrm{LiAlO}_{2}$ (19). Concernis over grain growth at high temperature can be alleviated by extrapolation of FUBR results: no significant gralin growth was observed over the range 500 to $900^{\circ} \mathrm{C}$. Likewise, extrapolation of both FUBR results and thermodynanic calculations (18) indicate no significant ceramic vapor phase transport at high temperatures, unlike. the case for $\mathrm{Li}_{2} \mathrm{O}$. Another concern might be the effect of high lithium burnup rates in the first row pins: all lithiun-6 would likely be converted to tritiun over the expected three year blanket lifetine. Although unexpected ceramic properties aight become evident, no serious structural transformations can be foreseen. The final ceranic might be closer to $\mathrm{Al}_{2} \mathrm{O}_{3}$ in conposition than to $\mathrm{LiAlO}_{2}$. If this severe burnup poses a problen, a lower percentage of lithium-6 enriehment for the first row would reduce both the burnup rate and the steep heat generation profile for this row, but at a cost of a greater parasitic neutron capture by the structural naterials in this region of the module, and thus a lower overall tritium breeding ratio.

As mentioned before, the method of characteristic grains is used to model inventory within each rod. As a first approximation, the ceranic portion of each rod was divided into five concentric zones of equal width. Within each zone, the volumetrically-averaged position was determined and the temperature at that position calculated from the temperature profile across the pin. This temperature was used to represent a characteristic grain for each zone. DIFFUSE gave the diffusive steady-state inventory for each of these grains in wppa. This inventory was scaled up for the nass of each zone, and the inventorfes of the five zones added to give a total inventory for the pin. Knowing the number of pins per each row per nodule and the number of nodules over the entire blanket, the total inventory for each row was determined and these values sumed for the total blanket inventory. This method gave a total blanket inventory of $12.9 \mathrm{~g}$.

Because diffusive inventory is heavily weighted toward the colder regcons of the rods, the possibility of understating the inventory existed with this 
method. As a better approximation, the outermost zone of each rod was divided into two smaller zones of equal thickness, a representative temperature for each zone determined as before, and the zonal inventories and total blanket inventory again extrapolated from the DIFFUSE results. This six-zone nethod resulted in a total blanket inventory of $13.3 \mathrm{~g}$, only $3 \mathrm{~g}$ greater than the 5-zone approximation.

To obtain a more precise determination of blanket inventory than these approximate methods could give, the governing analytical equations were manipulated into a form amenable to numerical analysis independent of DIFFUSE. Again, the spherical grain model of equation (39) was used as the basis. The average intragramular inventory within the pin can be calculated from:

$$
\bar{I}_{g r}=\frac{\int_{V} I_{d} d V}{\int_{V} d V}
$$

Using equation (39) to substitute for $I_{d}$ and evaluating the volune integrals across the hollow cylinders, an equation amenable to nunerical analysis was obtained:

$$
\overline{\mathrm{I}}_{g r}=\frac{2 r_{g}^{2} \dot{G}}{15 D_{0}\left(r_{0}^{2}-r_{i}^{2}\right)} \int_{r_{i}}^{r_{0}} \exp (Q / R T) r d r .
$$

After insertion of the temperature T-T(r) obtained from the calculated profile across the ceramic pin, this equation provided the average grain inventories for each row of pins. A total blanket inventory of $13.2 \mathrm{~g}$ tritium was directly obtained from these results, independent of but in very good agreement with the DIFFUSE-based results. Figure 13 gives the total row-by-row inventories obtained with this nunerical method, showing the predominance of inventory within the cooler small pins of rows 2 through 5 . The inventories of rows 2 through 5 approach 0.6 wpin while rows 6 through 11 have less than 0.02 wppa and row 1 about 0.03 wppn tritiun. If inventories are a major concern, this figure suggests talloring the pin dianeters in increasing size away from the plasma, to maintain consistently high ceramic temperatures for each row of pins.

The results of these three methods are plotted, row by row, in Figure 14. Significant agreement exists between all three nethods, further supporting the validity of the DIFFUSE-based inventories. These resilts compare favorably with the GA model total of $38.3 \mathrm{~g}$ for a $522, \mathrm{COO} \mathrm{kg} \mathrm{LiAlO}_{2}$ blanket (14) vs, $129,000 \mathrm{~kg}$ for this blanket design. But the GA nethod (using the TRIT4 code) analyzes only one unit coll, with the uncertainties it ioplies for tritium diffusive inventories. The exact temperatures and other input paraneters are never stated, preventing aore detailed comparison.

Because of: the large number of DIFFuSE runs needed to characterize the total Inventory in the above mathods (five to $s i x$ runs per rod, eleven rows of rods over the blanket), a simpler approach was required to model each rod during transient and start-up/shutdown operations. Again, equation (39) was used as the starting point, but now an equation for an average teaperature representative of the total pin inventory was desired: 
Figure 13

TOTAL BLANKET INVENTOAY, ROW BY ROW

$\approx$

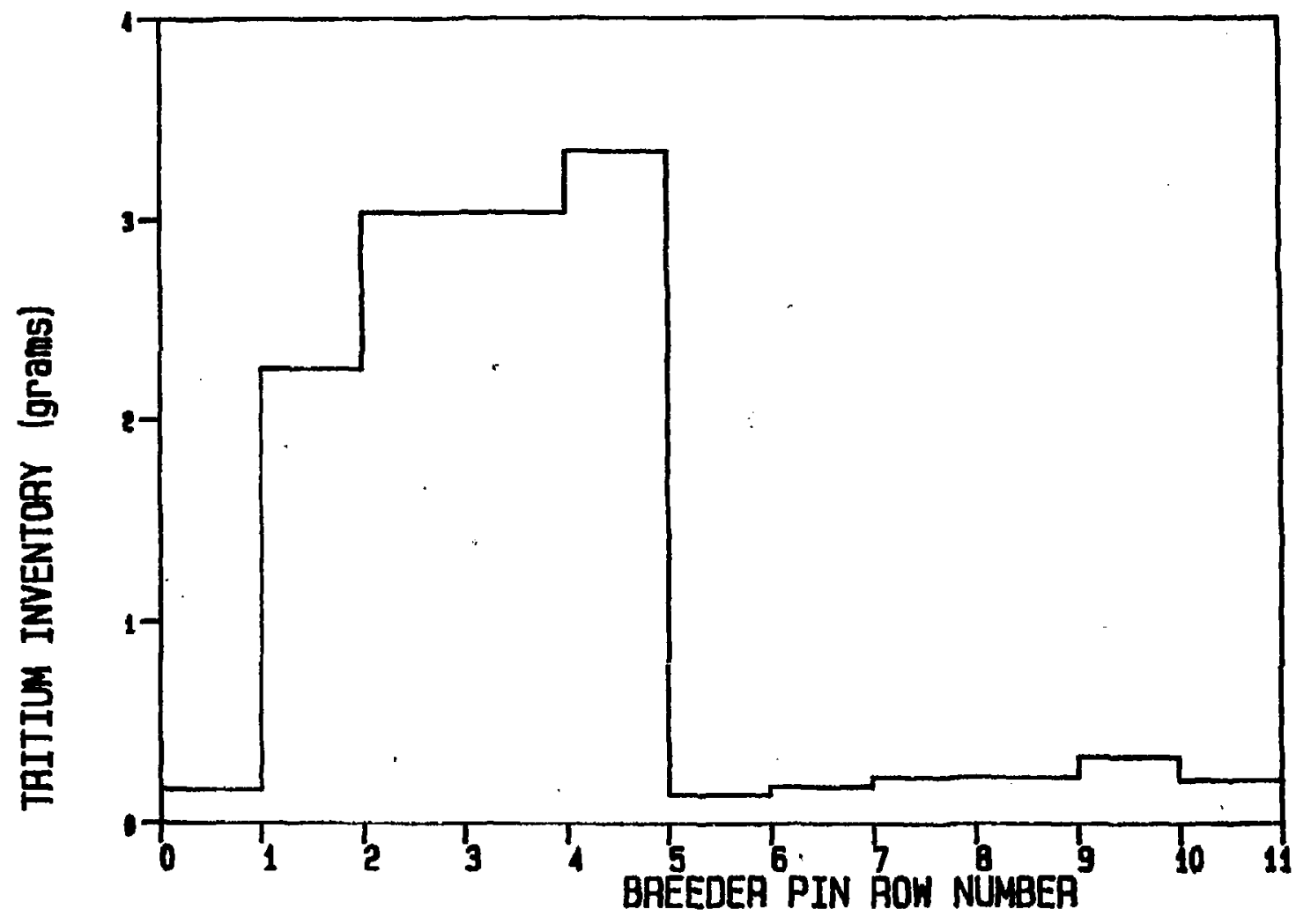


Figure 14

\section{COMPARISON OF TRITIUM INVENTORY MODELS}

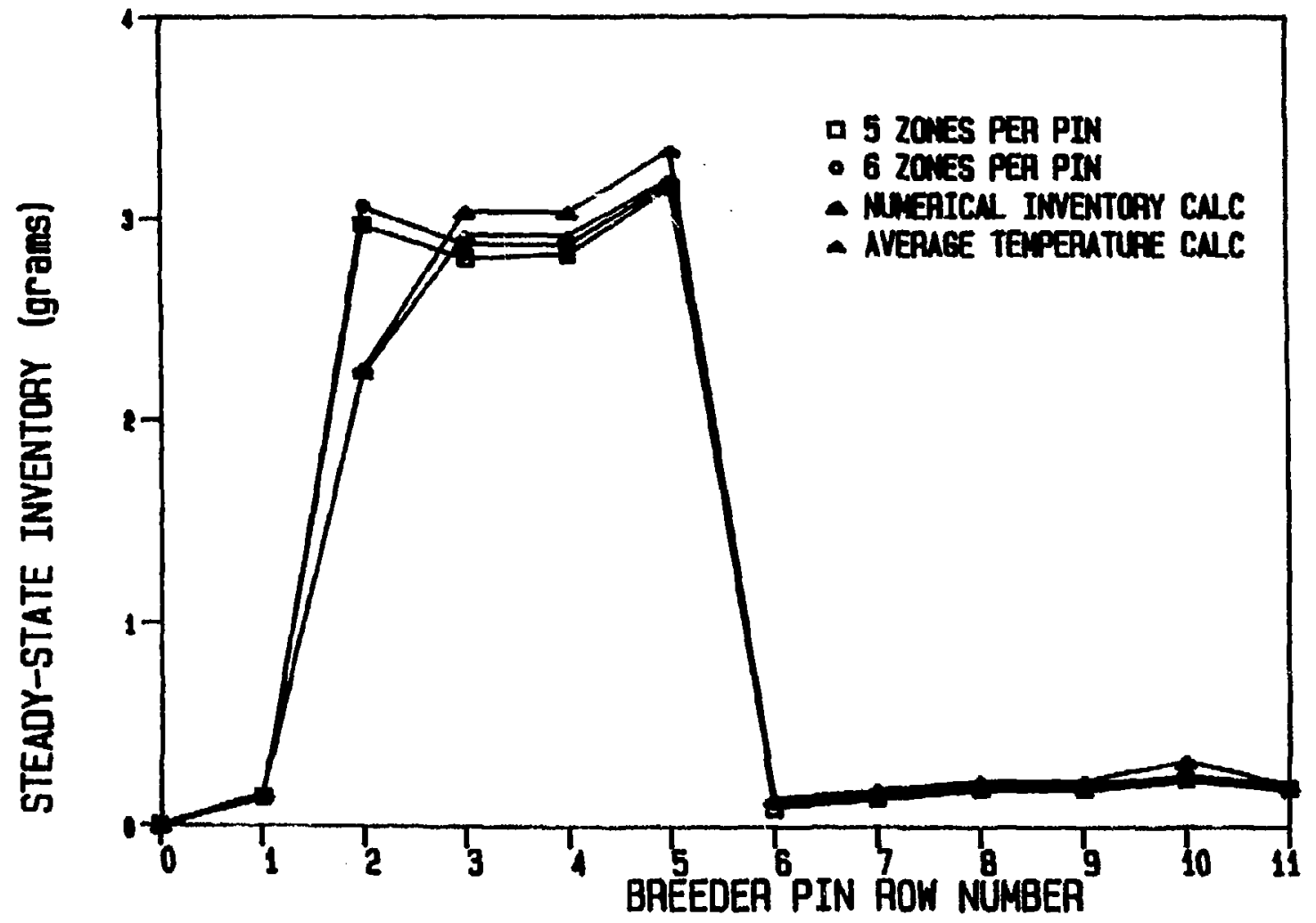




$$
I(\bar{T})=\frac{r_{g}^{2} \dot{G}}{15 D_{0} \exp (-Q / R T)}=\frac{\int_{V}^{I_{d} d V}}{\int_{V} d V} .
$$

Manipulation of this equation gives:

where

$$
\overline{\mathrm{T}}=\frac{Q}{R \ln \left(\frac{2 \xi}{r_{0}^{2}-r_{1}^{2}}\right)}
$$

$$
\xi=\int_{r_{i}}^{r_{0}} \exp (Q / R T) r d r .
$$

Substitution of the pin temperature profile into equation (44) allows numerical evaluation of the diffusion-averaged temperature for each row of rods, and a DIFFUSE analysis was made at each of these temperatures for a single characteristic grain representative of an entire rod. The steady-state inventory for each grain was scaled up for the entire rod, then for each row, to give new values of total row-by-row blanket inventory. These results are also shown in Figure 14, and gave a total blanket inventory of $12.6 \mathrm{~g}$. These results agree very well with the previous methods, with less than 58 variation from the results of the non-DIFFUSE numerical approximation method. Thus, reasonable inventory results can be obtained for an entire rod using only one DIFFUSE-analyzed characteristic grain at a temperature calculated from equation (43).

This result shows the single grain model to be ideal for transient analyses: by calculating the temperature profile for a rod under different power levels, an average temperature can be determined for each power level at which to analyze the characteristic grain with DIFFUSE. By assuming step changes in the power levels, the transient behavior of a rod can be simply modeled by a series of consecutive DIFFUSE runs for the sane grain at different temperatures and generation rates, with the resultant diffusive concentration profile within the grain from one run used as an initial concentration profile for the next run. DIFFUSE is set up to perform exactly this kind of sequential analysis, thus making transient analyses very convenient.

\section{TRANSIENT TRITIUM INVENTORY}

\section{Start-up}

Reactor start-up was modeled for two different situations. The first considered hellun coolant flow at 100\% of full power status. The second considered significantly reduced hellum flow during the transients to achieve higher operating tenperatures and lower transient tritiun inventories.

The transients modeled were at 108, 20\%, 508; and 808 of full power, each lasting 3.5 days, followed by 1008 power. The percentage of full power was 
used to scale the volumetric heating rates for ceramic and cladding accordingly, and likewise for tritiun generation rate. The rise in coolant temperature from nodule entrance (constant at $250^{\circ} \mathrm{C}$ ) to each row of pins was taken as a corresponding percentage of the tenperature rise at full power. The heat transfer coefficient frow cladding to coulant was adjusted accordingly. These values were used to calculate the temperature profiles inside the pin for each row at each transient power level, and these results used to calculate a characteristic temperature for each rod during each transient, to use as DIFFUSE input as mentioned previously.

With oach characteristic grain evaluated by DIFFUSE over several transients, the diffusive inventory can be obtained from the DIFFUSE output at any point during the two weeks prior to full power. After two weeks the input paraneters were set at full power values, and the inventory soon returned to 1ts steady-state values. Thus, after oleven DIFFUSE runs, each with several transients and each analyzing a characteristic grain for each row of pins, the results are scaled up for total blanket mass per row. The total transient inventories are obtained $a g$ a function of time for each row, and summed for the total blanket inventory.

The transient results involving 1008 helium flow gave total blanket Inventories of $226 \mathrm{~g}$ after 3.5 days at $10 \mathrm{t}$ power, $621 \mathrm{~g}$ after 3.5 days at $20 \%$ power, $429 \mathrm{~g}$ at 508 power, $61 \mathrm{~g}$ at $80 \%$, and a short time at 100\% returned the total inventory to the steady-state value of $12.6 \mathrm{~b}$. These results are plotted in Figure 15, and the row by row results in Figures 16 and 17 . The inventories are obviously much higher than steady-state during 10\%, 20\%, and 508 power levels, reaching several hundred grans with the biggest contribution from the first row and its dominant tritiun generation rate. The characteristic temperatures ranged from 550 to $590^{\circ} \mathrm{K}$ at 10 power, 590 to $650^{\circ} \mathrm{K}$ at $20 \%, 680$ to $830^{\circ} \mathrm{K}$ at $50 \%, 780$ to $1010^{\circ} \mathrm{K}$ at $80 \%$, and 840 to $1130^{\circ} \mathrm{K}$ at full power. The tenperatures fall within the regine of very slow tritium diffusion for 10 to 50 s pwer, leading to rapid build-up of the bred tritiun within the pins.

These significant inventorles sould lead to safety-related concerns of large blanket inventary, especially for protracted start-up tines at these temperatures. For this reason, the sane start-up regime was re-analyzed under conditions of restricted helium flow, reducing the rate of cooling and allowing higher temperatures to be achieved within the ceranics. For the I0: and 20\% power transients, the hellun flor rate was set at 20 of that at full power. Thus, at 20 s of full power the sane coolant tenperature should be obtained for each row as at 100\% full power. Likewise, at $50 \%$ and $80 \%$ of full power the helium flow rate was set at 50 s and 808 of full power, again giving the same coolant temperatures. For $10 \mathrm{~s}$ of full power, with heliun flow set at 208 the rise in temperature between blanket inlet and the row in question was taken to be one haIf that at full power. The volunetric heating rate and tritiun generation rate were scaled down from full power according to the translent power level as mentioned previously. New tenperature profiles across the pins were recalculated for each transient, characteristic temperatures evaluated for each transient at each row and the transient analyses rerun as before.

Due to considerably higher ceranic temperatures under these conditions of controlled coolant flow, the total blanket inventorles were greatly reduced 
Figure 15

TOTAL TRITIUM INVENTORY DURING STARTUP TRANSIENTS

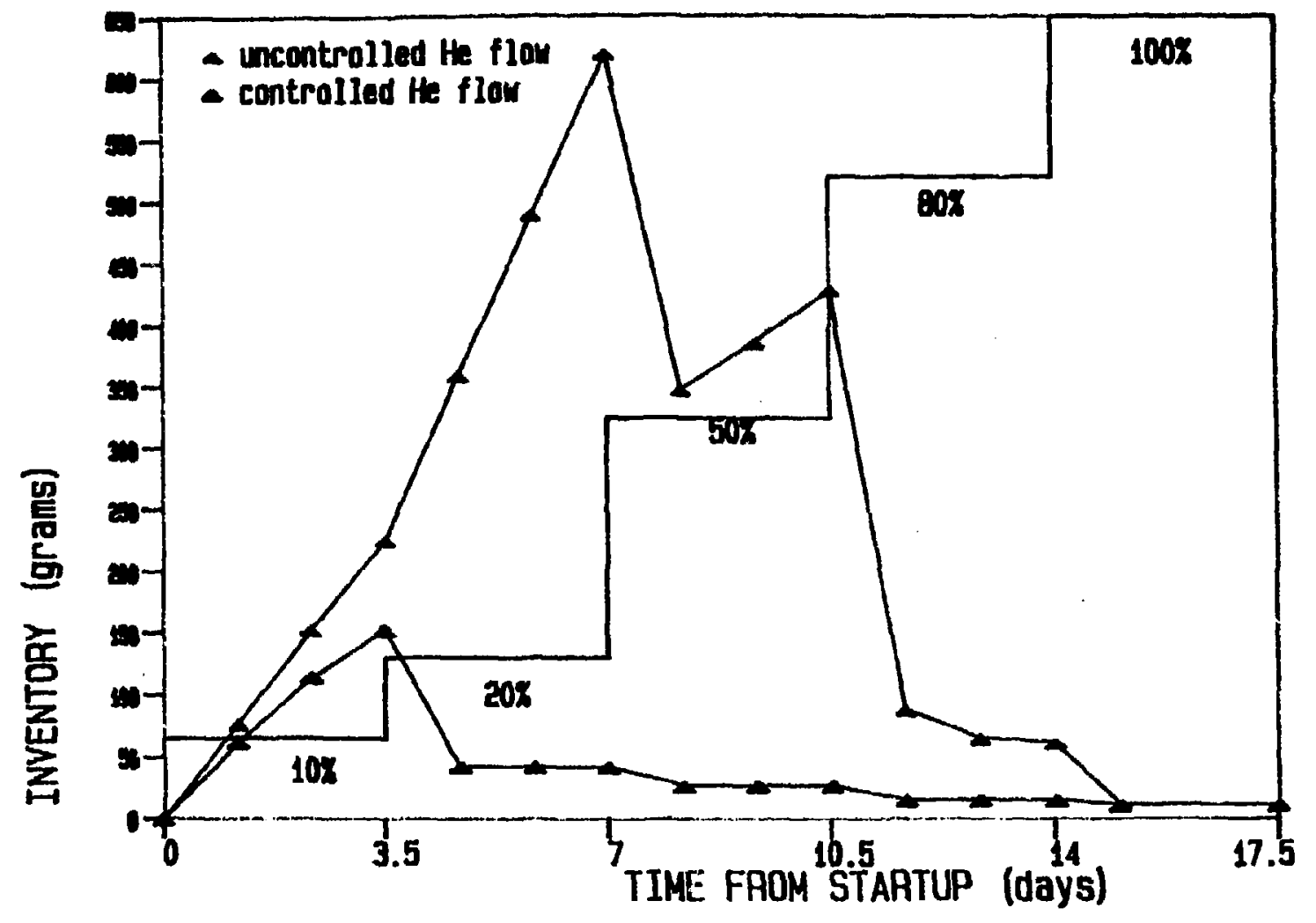


Figure 16

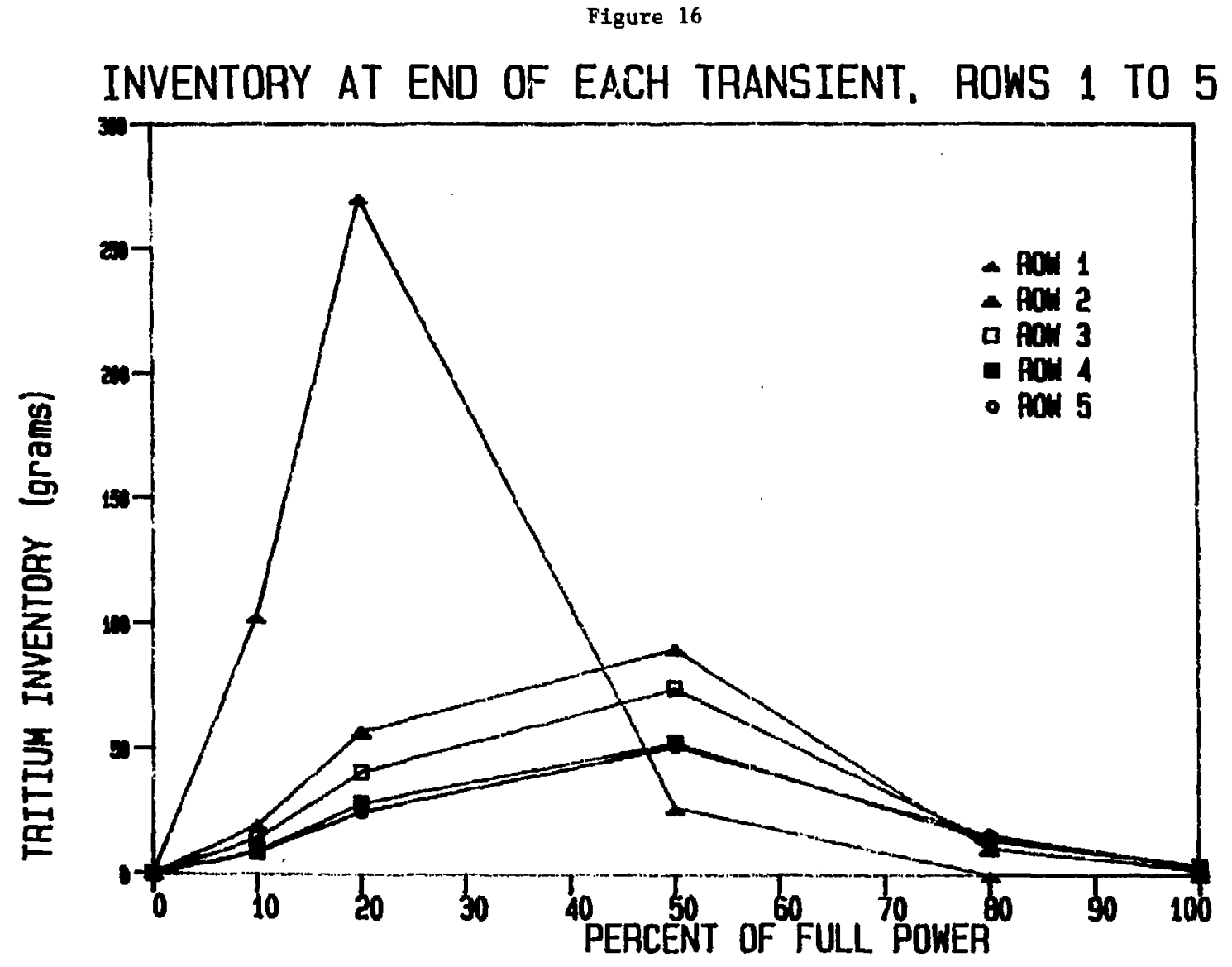


Figure 17

INVENTORY AT END OF EACH TRANSIENT, ROWS 6 TO 11

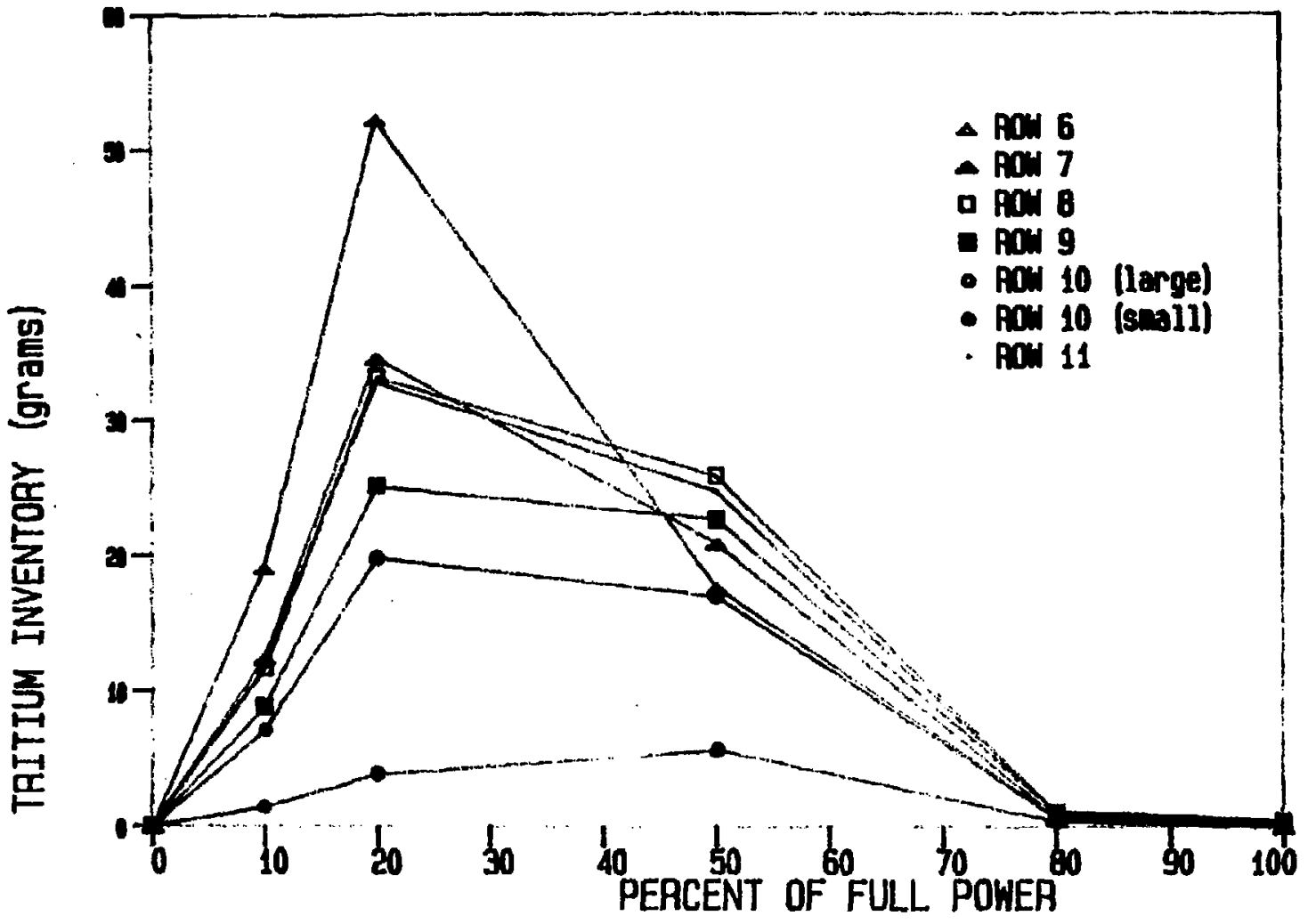


from the uncontrolled flow transients. The results give total inventorfes of $153 \mathrm{~g}$ at $10 \%$ after 3.5 days, $40.2 \mathrm{~g}$ at $208,25.6 \mathrm{~g}$ at $50 \mathrm{z}$, and $16.5 \mathrm{~g}$ at $80 \%$. These results are also shown in Figure 15.

The results for these two cases clearly show the need for talloring the helium flow rate to the transient power levels. An extended start-up could lead to massive inventories for uncontrolled conditions. Even with controlled flow, a gradual inventory build-up might be a concern for low power levels over an extended period of testing. In this case, supplemental pre-heating of the coolant would alleviate such concerns. Further study of the minimum practical helium flow rates is also warranted: tie minimun of 208 of full power flow is a conservative estiante, to avoid problems with flow instabilities."

\section{Shutdorn}

For shutdown, two different cases were analyzed: (1) coolant flow at 208 that for full power and (2) a conblnation of coolant flow reduction and heating such that the coolant teuperature ranged fron $470^{\circ} \mathrm{C}$ to $500^{\circ} \mathrm{C}$ across the pins. This second scenarlo can be thought of as "baking" the blanket to speed its purging of tritium inventory. Both scenarios assune afterheat volumetric generation of 18 that of full power and zero tritiun generation.

For the first case, that of simply reducing the helium flow, the temperature of the coolant entering the blanket was again $250^{\circ} \mathrm{C}$, and the temperature rise at each row of pins was taken to be 1/20 that of full power. These new coolant temperatures, 1t volumetric heating, and a corrected heat transfer coefficient were used to calculate new temperature profiles ocross the pins as before, and diffusion-averaged temperatures were again calculated for each pin. These temperatures were used as input to DIFrUSE along with zero generation rate as an additional step following the analysis for the three year run at 100 s power. Thus, the characteristic grains start with their steady-state inventories, then instantaneous shutdown occurs at which no nore tritium is generated but the steady-state concentration profiles within each grain are now subjected to the nuch lower temperatures at shut-down. As can be expected, tritiun diffusion from the grains slows down drastically. The diffusive Inventories are modeled for a year after shutdown, with total blanket inventory calculated as before.

Figure 18 shows that, after two weeks, the total inventory is reduced fron the steady-state full-power inventory of $12.6 \mathrm{~g}$ to $12.4 \mathrm{~g}$, only a $1.6 \mathrm{t}$ decrease in total inventory. At the end of $s i x$ months at these shutdown conditions an inventory of $12.1 \mathrm{~g}$ still remains and after one year an inventory of $11.7 \mathrm{~g}$, indicative of the almost negligible rate of diffusion at these cold shutdown temperatures. With all the characteristic temperatures near $540^{\circ} \mathrm{K}$, only 7.18 of steady-state inventory is purged after one year.

In comparison, the characteristic grains are then nodeled for hot shutdown, with the coolant temperatures nentioned before. Again, new row by row temprature profiles were calculated, average tenperatures evaluated from these, and the previous analyses rerun at these higher temperatures. As could be expected, the result was a significantly accelerated tritiw purge from the blanket. Figure 19 shows that, after only one week, the total Inventory was reduced from $12.6 \mathrm{~g}$ to $0.45 \mathrm{~g}$. After two weeks, inventory was reduced to an insignficant $0.02 \mathrm{~g}$. Thus, with characteristic temperatures ranging from 750 
Figure 18

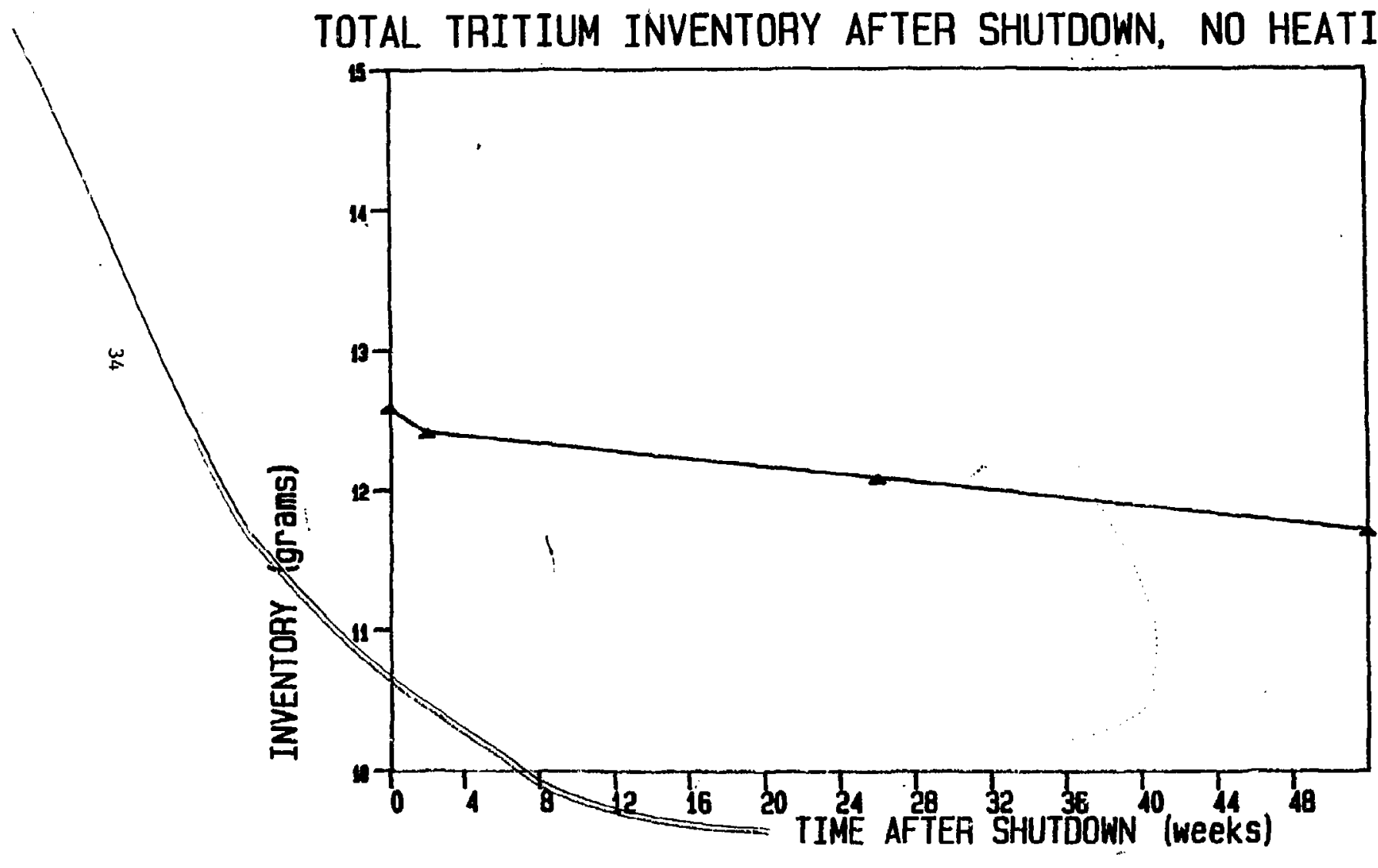


F1gure 19

TOTAL TAITIUM INVENTORY AFTER SHUTDOWN

岕

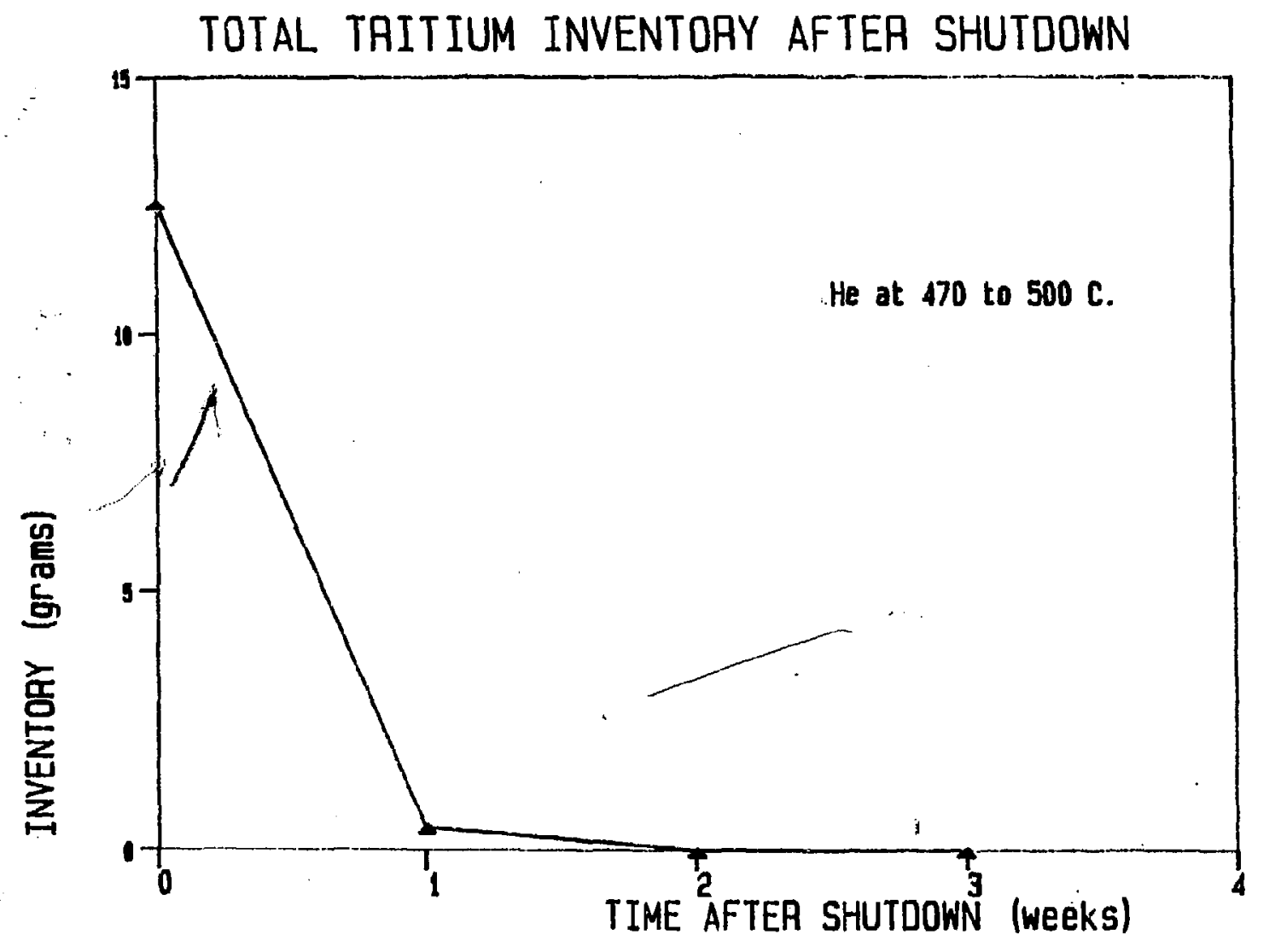


to $780^{\circ} \mathrm{K}$ and no tritiun generation after shutdown, tritium purging can be considered complete after only two weeks.

For less than $13 \mathrm{~g}$ steady-state inventory, a question could arise whether such baking with the extra expense of heating the coolant is actually needed. However, if the final blanket is not as "clean" as our idealized model would indicate, this analysis shows that baking could rapidly clean out the major portion of the blanket inventory after shutdown. Such auxiliary heating should alleviate inventory concerns in a post-shutdown environment.

\section{ADDITIONAL DIFFUSE MODELING}

Completely Dense Pins

DIFFUSE was used to model a hypothetical case for steady-state inventory and release for this rod design, but using a ceramic pin of 100 theoretical density rather than 85 as assuned in this study. The purge channel was rotained but the tritiun was considered to be generated in and diffuse through one giant hollow cylindrical crystal of $\mathrm{LiAlO}_{2}$ rather than a ninute spherical grafn. The boundary conditions were taken to be a perfectly reflecting outer surface (i.e. an inner bxido layer on the cladding) and zero concentration on the inside purge channel surface.

These 100 dense pins were analyzed for rows one, five, and eleven. The values for inner and outer surface temperatures were taken from the original $85 \%$ dense pins (although detailed alalysis would require recalculation of temperature based on the changed thermal conductivity). DIFFUSE assumes a Iinear temperature profile rather than the actual parabolic design, slightly overestimating inventory and underestinating: release. The same tritium generation rates were used as in the original pin design.

For row one, the ninimun temperature is $1017^{\circ} \mathrm{K}$ and the maximun is $1410^{\circ} \mathrm{K}$. After three years of steady-state operation, DIFFUSE evaluated the inventory of each pin to be $21.0 \mathrm{~g}$ of tritiun, or over $350 \mathrm{~kg}$ for the first row over the entire blanket, an extremely high inventory. For row five, with tenperatures fron 809 to $891^{\circ} \mathrm{K}$, the inventory for each pin was found to be $1.76 \mathrm{~g}$ and over the whole blanket nearly $30 \mathrm{~kg}$. For row eleven, with temperatures frov 900 to $1155^{\circ} \mathrm{K}$, the single pin inventory was $6.30 \mathrm{~g}$ and the total blanket inventory about $40 \mathrm{~kg}$. Obviously, the first row-Inventory will doninate the total due to the high generation rate.

The complement of high inventory is low release. Over three years, the entire first row would release $6.7 \mathrm{~kg}$ into the purge strean, or $1.7 \mathrm{~s}$ of the total tritiun generation. With their colder operating temperatures, rows five and leven would release only $a$ few hundredth of a percent of their total generation: all of row five would relesse a mere $1.0 \mathrm{~g}$ tritiun, and row eleven only 6.9 g. Except for the relatively hot first row rods, tritiun release over three years would be negligible.

The importance of these results is the lack of any significant release for nost of the pins over the entire blanket lifetime, raising the possibility of using 100* dense $\mathrm{LLAlO}_{2}$ pins and batch processing the retained tritium at the ond of blanket life. Elimination of the purge channels as superfluous 
would provide more breeder mass in the blanket and a higher breeding ratio. Hore significant is an increase of over 17 in breeder mass in using 1008 vs. 85\% density, with its major impact on tritiun breeding ratio. With no purge channel, total release fron the colder outer zones of the pins through the oxide barrier of the cladding would likely be insignificant. Structural integrity of the deranic during burn-up would be enganced, considering the results of the FUBR-1A experiment (19). Actual permeation losses over lifetime would likely be less than with perneation through the purge system.

The main disadvantage to this concept is of course very high inventories, but this should not affect safety concerns as long as all pins remain intact over lifetime. Retention of tritiun the entire three years would lead to enhanced decay to helium prior to extraction, but DIFFUSE indicates total decay to be 8 of all bred tritiun, insignificant considering the 17.68 increase in breeder mass and breeding ratio with $100 \mathrm{ks}$. 85 tense $\mathrm{LiAlO}_{2}$. A major concern is the presence of any grain boundaries in the 100 dense pin, leading to more rapid diffusion than our ideal single grain cylinder. This problen would be alleviated by retaining the purge channels to handle such diffusion.

Although the inventory levels with these dense pins appears frightening, the structural integrity of the pins over blanket lifetine mitigates the safety concerns. The advantages obtainable from these dense pins might encourage Future consideration.

\section{Qther Inventory Phenomena}

A11 previous DIFFUSE analyses assuned a zero tritiun concentration on the surface of a spherical grain, analogous to previous modeling efforts. However, TRIO (6) assuned a significant surface inventory under a pure helium purge strean to explain the experimental results. Solubility effects are known to be significant for $\mathrm{Li}_{2} \mathrm{O}$. Concern exists over irradiation effects and the possibility of production of traps for tritiun which night significantly increase inventory.

As a very prelininary indication of the versatility of the DIFFUSE code, several analyses were nade under different conditions. Using input paraneters for $\mathrm{LiAlO}_{2}$ felt to be reasonable (due to the lack of relevant experfmental data), both Sievert's Law (solubility effects) and surface reconbination boundary conditions were compared to zero surface concentration over a range of temperatures, all other parameters held constant. In addition, an analysis was made assuming a trap concentration of 1 atomic fraction and a trapping energy of $2 \mathrm{eV}$. Results are presented in Figure 20.

For all temperatures below $1100^{\circ} \mathrm{K}$, these other phenomena show no effect on total inventory, indicating diffusive inventory to be overwhelining. However, at higher temperatures, measurable additions to diffusive inventory are apparent. Radiation trapping under these conditions is insignificant, but surface recombination becomes significant and solubility very significant as temperature becones very high. However, with an anbient tritium gas presaure of one torr assuned, these solubility results may overstate actual operating concentrations.

These linited results are not significant without further analysis, but the potential of DIFFUSE for additional analyses into these phenomena ia 
Figure 20

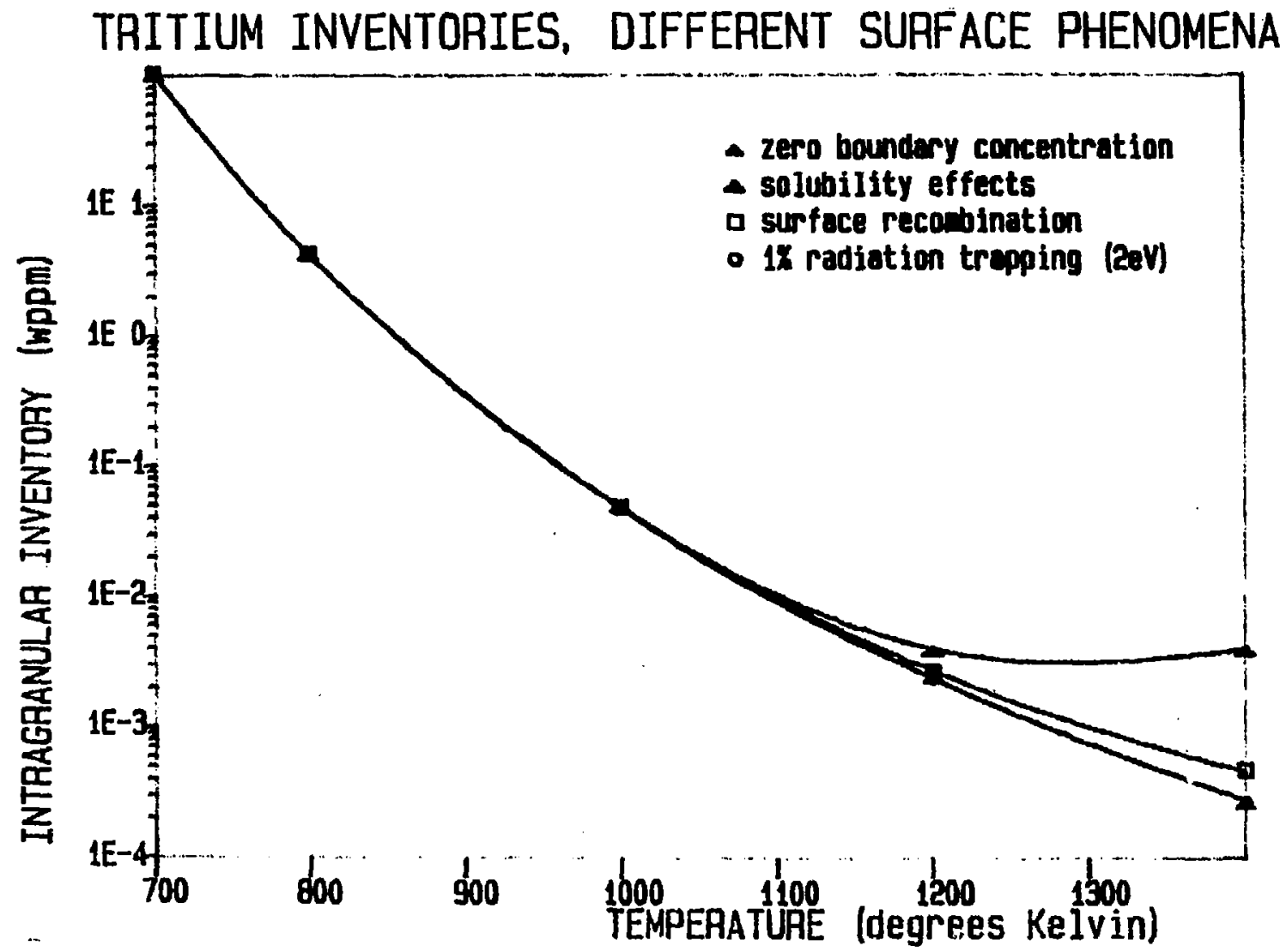


obvious.

\section{Radiation Trapoing}

Some paranetric analysis using DIFFỤSE has been done (23) to estinate significant tritiu trapping regimes under irradiation, 1.e. comblnations of temperature, trap concentration, and trapping energy with which significant contributions are made to total inventory. The results are not presented here, but will be briefly sumarized.

No experinental determination of tritiun trapping energies in lithium ceranic breeders due to irradiation has been made. Trapping energles for helium in netals is known to be 1.5 to $2.5 \mathrm{ov}$, but the lonic nature of the diffusing triton prevents direct comparison. DIFFUSE analysis of tritium trapping in $\mathrm{LIAlO}_{2}$ was made at two temperatures over a range of trapping energies fron $1.5 \mathrm{eV}$ to $4.5 \mathrm{eV}$, all other parameters held constant, and an assumed trap concentration of 1 appn. At $773^{\circ} \mathrm{K}$, trapped inventory was insignificant, reaching only a few percent of diffusive inventory at a $4.5 \mathrm{eV}$ trap energy. At $1273^{\circ} \mathrm{K}$, diffusive inventory is greatly reduced, and trapped inventory equals diffusive at about $4 \mathrm{eV}$ and greatly exceeds diffusive at 4.5 ev.

For an assumed trap energy of $3.5 \mathrm{eV}$ and a temperature of $1273^{\circ} \mathrm{K}$, the relative inventories were compared as a function of trap concentration. At 1 appn traps, trapped inventory is insignificant. At a trap concentration of about $10^{-4}$ aton fraction, the two inventorles are equal. At higher trap concentrations, the trapped inventory rapidly increases.

Finally, given a trap concentration of 18 atomic fraction, trapped and diffusive inventories were compared between 700 and $1475^{\circ} \mathrm{K}$ for trap energies of $2.5 \mathrm{eV}$ and $3.5 \mathrm{eV}$. For $2.5 \mathrm{eV}$ the trapped inventory is predominant at $750^{\circ} \mathrm{K}$, equals diffusive at about $825^{\circ} \mathrm{K}$, and rapidly becones insignificant to that of diffusive at higher temperatures. For $3.5 \mathrm{eV}$, the trapped inventory is overwhelning at all but the highest temperature, where it is still an order of magnitude above the diffusive inventory.

Lack of experinental analysis of radiation damage effects in LiAlO prevents direct application of DIFFUSE results to blanket design and englneering. These limited results suggest trapping energies approaching $3 \mathrm{eV}$ are significant for high trap concentrations 1.e. at high lithiun burn-up fraction. For low trap concentrations (1 appm) the trapped inventory becomes significant at higher temperatures, while an inverse temperature effect occurs for 13 atomic fraction of traps. Much nore analysis is required to determine the significance of radiation effects on tritium inventory. Hypotheses of tritiun trapping mechanisms remain rudinentary at best $(24,25)$.

\section{SUMMARY AND RECOMMENDATIONS}

This section of the pin-type solid breeder blanket study is the first detailed attempt at modeling tritiun inventory and release within a fusion reactor blanket based on actual tritiun generation and thernal hydraulic profiles, rather than a simple average unit cell extrapolation or some assumed exponential profiles. 
The DIFFUSE 83 code was found to give inventory results consistent with previous nodeling efforts and with the general spherical grain nodel.

The inventories for this blanket dasign calculated using DIFFUSE were found to be very satisfactory, less than $14 \mathrm{~g}$ at steady-state for a $129,000 \mathrm{~kg}$ $\mathrm{LAAIO}_{2}$ blanket. This rosult is reasonable compared with a BCSS $\mathrm{LiAlO}_{2}$ blanket inventory calculated by GA Technologies.

DIFFUSE was found to be very useful in approxinating tritiun inventories during transient start-up/shutdown nodes. The evaluations of transient inventories in this study appear to be the nont detalled to date. The results suggest the need for controlling coolant flow during start-up to maintain high breeder temperatures and low tritiun inventory, and the use of pre-heated coolant to "bake" out tritiun inventory after shut-down.

DIFFUSE modeling of breedar pins of 100 theoretical density indicates very linited tritium release from the $\mathrm{LiAlO}_{2}$ cerauic, suggesting batch processing of the pins for tritium extraction at the end of blanket lifetine.

Preliminary analysis of other surface and radiative trapping effects shows DIFFUSE to be potentially a very useful tool in approximating and evaluating experimental results. Additfonal DIFFUSE analysis of these effects given the available experimental data is warranted.

Another logical area for DIFFUSE analysis is tritium permeation of the pin cladding and structure within the blanket. This area will be pursued in the future.

A real need for modeling of tritfun behavior in ceramic breeders is a broader experimental data base. Order of magnitude approximations and unknown diffusive and trapping nechanisns for tritiun are inappropriate for detailed nodeling of trittum behavior and accurate estimates of tritiun inventory, permeation, and release within fusion reactor solid breeder blankets.

\section{ACKNOWLEDGEMENTS}

Support by a University of California Los Angeles Chancellor's Fellowsh1p is gratefully acknowledged. The support of Department of Energy, Grant "DE-FG03-80ER52061 to UCLA is appreciated. 
REFERENCES

1. C. E. Johnson and G. W. Hollenberg, "Recent Advances in the Development of Solld Breeder Blanket Materials," J. Nucl. Mater. $122 \&$ 123, 871-881 (1984).

2. M. Abdou et a1., "Blanket Comparison and Selection Study - Fina1 Report," Argonne National Laboratory Report ANL/FPP-84-1 (1984).

3. M. Abdou et a1., "FINESSE: A Study of the Issues, Experiments and Facilities for Fusion Nuclear Technology Research and Development", Interim Report, VoI. 3, PPG-821/UCLA-ENG-84-30 (1984).

4. D. Guggi et al., "Diffusion of Tritium in Single Grystal $\mathrm{Li}_{2} \mathrm{O}$ ", J. Nucl. Mater. 118, 100 (1983).

5. D. Britining, D. Guggi, and H. R. Thle, "The Diffusivity of Tritiun in the System $\mathrm{Li}_{2} \mathrm{O}-\mathrm{Al}_{2} \mathrm{O}_{3}$," Proc. 12th Symp. on Fusion Technology, 1982, Jülich, FRG, EUR 7983 EN, PP. 543-548.

6. R. G. Clemner est al., "The TRIO Experinent", Axgonne National Laboratory Report ANL-84-55 (1984).

7. M. Tetenbaum and C. E. Johnson, "Partial Pressures of $\mathrm{H}_{2} \mathrm{O}$ Above the Diphasic $\mathrm{LI}_{2} \mathrm{O}(\mathrm{s})$ - $\mathrm{LIOH}(\mathrm{s}, 1)$ System," J. Nuc1. Mater. 126, 25-29 (1984).

8. D. Donne and Dorner, "Sone Considerations on Tritiun Control in a He-cooled Ceramic Blanket for the NET Reactor," KFK-3755 (1984), P. 39.

9. M. Tetenbaun, A. K. Fischer, and C. E. Johnson, "An Investigation of the Solubility of LiOH in Solid Li ${ }^{0}$," Fusion Technology Z, 53-56 (1985).

10. JANAF Thermochemical Tables, 2d ed., D. R. Stull and H. Prophet, project directors, NSRDS-NBS37, June 1971.

11. C. C. Baker et al., "STARFIRE - A Commercial Tokamak Fusion Power Plant Study", Argonne National Laboratory Report ANL/FPP-80-1 (1980), p. 10-94.

12. M. Abdou 소 al., "FINESSE," 1bid., p. 5-88.

13. M. Abdou et a1., "Blanket Comparison and Selection Study," ibid., p. $6.3-103$.

14. 오. citt., p. 8-147.

15. ㅇ․ c1t., p. 6.3-108.

16. M. Abdou et al., "FINESSE," ibid., p. 5-106.

17. K. Noda et el., "Radiation Damage in Sintered Li 20 Pellets - EsR Study", J. Nuc1. Mater. 91, 234 (1980). 
18. C. E. Johnson and A. K. FIscher, "Blanket Materials for Fusion Reactors: Comparisons of Thermochemical Performance," J. Nuc1. Mater. 130, 445-453 (1985).

19. G.W. Hollenberg, "Fast Neutron Irradiation Results on $\mathrm{Li}_{2} \mathrm{O}, \mathrm{Li}_{4} \mathrm{SiO}_{4}$, $\mathrm{Li}_{2} \mathrm{ZrO}_{3}$, and $\mathrm{LiAlO}_{2} \mathrm{~N}, \mathrm{~J}$. Nuc1. Mater. $122 \& 123,896-900$ (1984).

20. K. I. Baskes, "DIFFUSE 83", SAND-83-8231 (1983).

21. M. I. Baskes et sl., "Tritium Permention Considerations in the MARS Direct Convertor," J. Nucl. Mater. 122 \& 123, 1511-1517 (1984).

22. M. Abdou et al., "FINESSE," libld., p. 5-87.

23. R. Martin, "Effects of Radiation Damage on Tritiun Diffusion in Fusion Solid Breeders," unpublished manuscript.

24. J, A. Shearer et a1., "Tritium Diffusion in Lithiun-Oxide Solid Breeder Materials," Annual Meeting of the American Nuclear Society, Detroit, MI, June 12-27, 1983.

25. M. Abdou et a1., "Blanket Comparison and Selection Study," ibid.. p. 6.3-73. 